\title{
Pasture usage by ancient pastoralists in the northern Kazakh steppe informed by carbon and nitrogen isoscapes of contemporary floral biomes
}

\author{
A. R. Ventresca Miller ${ }^{1,2,3}$ (D) T. M. Bragina ${ }^{4,5}$ - Y. A. Abil ${ }^{4}$ - M. M. Rulyova ${ }^{4}$ - C. A. Makarewicz ${ }^{2}$
}

Received: 8 August 2017 / Accepted: 22 May 2018 / Published online: 15 June 2018

(C) The Author(s) 2018

\begin{abstract}
Identification of variation in pasture use by domesticated livestock has important implications for understanding the scale of animal husbandry and landscape use in modern and ancient societies alike. Here, we explore the influence of pasture floral composition, salinity, and water availability on the carbon $\left(\delta^{13} \mathrm{C}\right)$ and nitrogen $\left(\delta^{15} \mathrm{~N}\right)$ isotopic composition of plants from the steppes of Kazakhstan. Our findings demonstrate geospatially defined differences in the isotopic composition of sedge marshes, saline marshes, and meadow steppes, information which we then use to inform animal management strategies used in the past. We then examine pasture usage by ancient livestock through carbon and nitrogen isotope analyses of bone collagen from animals that grazed in the northern Kazakh steppe. Pasturing strategies varied according to livestock taxa, with horses exhibiting lower $\delta^{13} \mathrm{C}$ and $\delta^{15} \mathrm{~N}$ values relative to cattle, sheep, and goat. We argue that horses, which are highly mobile and freely graze over pastures extending over wide areas, were grazed under an extensive pasturing system. These data suggest that the isotopic composition of contemporary vegetation communities can help inform animal management strategies used in the past.
\end{abstract}

Keywords Bronze age $\cdot$ Sintashta $\cdot$ Andronovo $\cdot$ Kazakhstan $\cdot$ Livestock $\cdot$ Pasture

Electronic supplementary material The online version of this article (https://doi.org/10.1007/s12520-018-0660-4) contains supplementary material, which is available to authorized users.

\section{A. R. Ventresca Miller \\ ventrescamiller@shh.mpg.de}

1 Graduate School for Human Development in Landscapes, Christian-Albrechts-Universität zu Kiel, Leibnizstr. 3, 24118 Kiel, Germany

2 Institute for Prehistoric and Protohistoric Archaeology, Christian-Albrechts-Universität zu Kiel, Johanna-Mestorf-Straße 2-6, 24118 Kiel, Germany

3 Department of Archaeology, Stable Isotope Group, Max Planck Institute for the Science of Human History, Kahlaische Strasse 10, 07745 Jena, Germany

4 Kostanay State Pedagogical Institute, Tauelsizdik street 118, Kostanay, Kazakhstan 110000

5 Federal State Budget Scientific Institution Azov Fisheries Research Institute, 21V Beregovaya street, 344002 Rostov-on-Don, Russia

\section{Introduction}

Pastoralists employ a diverse set of animal management strategies to ensure their subsistence and that of their herds. One important husbandry practice involves moving livestock to different pastures in order provide herd animals with a continuous source of fresh graze (Wright and Makarewicz 2015; Outram 2015). The spatial extent of pasturing systems and the intensity of pasture use depend on a complex intersect of ecological and social factors including seasonality, graze availability, water point, predators, stocking rate, and pasture access rights (Fernandez-Gimenez 2000, 2002; Kerven et al. 2006; Milner-Gulland et al. 2006; Kerven et al. 2016). While the intensity of pasture usage structures pastoralist movement and has direct consequences for the health of pastoral herds, little is known about pasturing intensity for different livestock species in prehistoric pastoralist contexts. Typically, contemporary pastoralists partition their herd animals into different groups depending on species, age, and animal value. These separate herds are then directed to different pastures according to the quantity and quality of pasturage in order to balance graze intake and (re)productive output (Fernandez-Gimenez 2000; Fernandez-Gimenez 2002; Kerven et al. 2016). 
The practice of partitioning herds and subsequent dispersal of animals to different pastures is widely practiced in pastoralist societies across the globe. Contemporary agro-pastoralists in Kazakhstan also employ several variants of this herd management strategy, taking advantage of diverse forage quality and quantity on the landscape, both of which vary on a seasonal basis (Robinson et al. 2003; Kerven et al. 2006; Schillhorn van Veen et al. 2003; Kerven et al. 2016). These include intensive pasturing strategies involving grazing of herds (cattle, goats) within $5 \mathrm{~km}$ of small villages and more extensive herding strategies that place herds onto distant pastures up to $20 \mathrm{~km}$ from settled areas (horse, cattle, sheep, goat) (Kerven et al. 2006, 2016). Some herders graze livestock at distant pastures more than $20 \mathrm{~km}$ from village while others entrust their livestock to owners of remote pastures (Kerven et al. 2006; Kerven et al. 2016). Pasture stocking rates (density of animals grazing per acre) vary depending on local environmental conditions that in turn influence the spatial extent of pasturing systems. For example, locations that receive higher amounts of precipitation, which promotes pasture growth, tend to support high herd densities even for heavily subscribed pastures located near villages (Robinson et al. 2003; Kerven et al. 2006; Kerven et al. 2016). Kazakh herders also divide small-stock and large-stock into separate pastures. Cattle are frequently grazed on low-quality forage (e.g., coarse reeds) in river floodplains and saline marshes located within 5 to $20 \mathrm{~km}$ villages. During the milking season, lactating cows and suckling calves are often grazed on higher-quality pastures located near villages (Robinson et al. 2003; Kerven 2016). Sheep and goats are often grazed in the open steppe where they feed on shorter herbs and finer grasses that can be grazed all year (Kerven 2016). While all livestock roam somewhat freely, horses are the most autonomous and least likely to be attacked by predators; therefore, they range the farthest from villages searching for appropriate vegetation (Kerven et al. 2016).

Establishing the scale and intensity of pasture use by different livestock species potentially provides insights into pastoralist adaptations to shifting graze availability and social landscapes (Honeychurch and Makarewicz 2016). However, the extent of pasture use by ancient steppe pastoralists has so far only been indirectly inferred based on the distribution, size, and occupation density of prehistoric settlements (Epimakhov 2002; Epimakhov 2009; Frachetti 2009; Hanks 2009; Batanina and Hanks 2013). Here, we explore pasture use by different livestock taxa during the second millennium cal BCE in the northern Kazakh steppe through carbon and nitrogen isotope analyses of caprines, cattle, and horse remains recovered from MBA sites of Bestamak, Kamennyi Ambar, and Bolshekaragansky alongside the LBA site of Lisakovsk. Stable isotope analysis provides a direct measure of livestock dietary intake and offers a powerful means to evaluate the spatial and temporal dynamics of pasture use in modern and ancient pastoralist societies (Makarewicz 2014, 2017). However, there is a dearth of information describing the distribution of carbon and nitrogen isotopes in steppe pastures which challenges a close understanding of the mechanisms influencing the carbon and nitrogen isotopic composition of livestock tissues. To this end, we analyze carbon and nitrogen isotopes of contemporary plants obtained from spatially disparate pastures located in distinct vegetation communities in the northern Kazakh steppe. In doing so, we broadly establish the relationship between water availability and soil salinity in the landscape and the distribution of isotopic composition of plants.

\section{Bronze age settlement, society, and subsistence in the northern Kazakh steppe}

The Middle to Late Bronze Age (2200 to $1400 \mathrm{cal}$ BCE) in the northern Kazakh steppe encompassed a major shift in settlement patterns from semi-sedentary pastoralism to more dispersed, mobile lifeways engaged in pastoral nomadism (Tkacheva 1999; Grigory'ev 2002; Koryakova and Epimakhov 2007; Kuz'mina 2007; Tkacheva and Tkachev 2008). Middle Bronze Age (2200 to 1700 cal BCE) settlements had large enclosures consisting of an earthen wall and ditch. Inside the enclosure, earthen domestic structures with shared walls (numbering from 30 to 60) housed an estimated 200 to 700 individuals (Gening et al. 1992; Grigor'yev 2002; Anthony 2007; Kohl 2007; Koryakova and Epimakhov 2007; Hanks 2009; Batanina and Hanks 2013). MBA settlements were repeatedly occupied, evidenced by successive building phases that added structures and enlarged enclosures. Aggregated MBA sites are situated between 40 and $60 \mathrm{~km}$ apart, and landscapes between enclosed settlements may have been territories of particular settlements (Epimakhov 2002; Zdanovich and Batanina 2002; Merrony et al. 2009; Stobbe et al. 2016). While there is currently no archeological evidence for structures such as animal corrals or walls outside of MBA settlement enclosures, open areas within settlements may have been used to house livestock. Reconstructions of landscape use in the vicinity of MBA sites determined that pastures within $4 \mathrm{~km}$ of the site could have supported herd sizes large enough to sustain sedentary livestock herders (Stobbe et al. 2016). During the subsequent Late Bronze Age (1800 to1400 cal BCE) settlements were more dispersed across the landscape and significantly smaller, consisting of fewer than 20 dwellings, further lacking enclosures and building phases (Kuz'mina 2007:36-8; Zakh and Ilyushina 2010). This shift in settlement size and distribution has been interpreted to indicate the emergence of nomadic pastoralism and the intensification of long-distance mobility (Tkacheva 1999; Grigory'ev 2000; Kuz'mina 2007; Tkacheva and Tkachev 2008).

MBA communities engaged in pastoralism and supplemented their diets with wild plants and wild game (Krause and Koryakova 2013; Ventresca Miller et al. 2014a; Hanks et al. 2018). A variety of wild plants have been recovered during flotation, but so far, domesticated grains 
have not been recovered (Krause and Koryakova 2013; Ng 2013; Hanks et al. 2018). Carbon and nitrogen stable isotope analyses of bone collagen indicate that human dietary intake in the MBA focused on terrestrial animal protein, likely in the form of meat and milk, which was supplemented by locally available fish and wild plants (Ventresca Miller et al. 2014a; Hanks et al. 2018). While the subsequent LBA has been interpreted as a shift to nomadic pastoralism, little data is available regarding landscape use or herd management strategies for this period. Paleodietary studies suggest that human diets during the LBA focused on pastoral products and were supplemented by wild plants, fish, and wild animals (Ventresca Miller et al. 2014a, 2014b).

\section{Carbon and nitrogen isotopes in steppe floral biomes}

The carbon isotopic composition of terrestrial plants varies according to photosynthetic pathway and modifying environmental variables. $\mathrm{C}_{3}$ pathway plants exhibit low $\delta^{13} \mathrm{C}$ values ranging from -20 to $-31 \%$ o while $\mathrm{C}_{4}$ pathway plants exhibit higher, but a more limited range, of $\delta^{13} \mathrm{C}$ values from -12 to $16 \%$ (O'Leary 1981, 1988; Farquhar et al. 1989). In the Eurasian steppe, floral biomes are composed of a mix of grasses and flowering nonwoody $\mathrm{C}_{3}$ plants and $\mathrm{C}_{4}$ grasses and Chenopodiaceae (Toderich et al. 2007). The carbon isotope composition of plants is influenced by salinity, aridity, and water availability. For $\mathrm{C}_{3}$ plants, water availability exhibits a negative relationship with plant $\delta^{13} \mathrm{C}$ values (Farquhar et al. 1989; Farquhar 1991; Stewart et al. 1995), while there is little to no correlation between water availability and the $\delta^{13} \mathrm{C}$ values of $\mathrm{C}_{4}$ plants (Farquhar et al. 1989; Swap et al. 2004; for slight positive correlation, see Murphy and Bowman 2009). Variation in $\delta^{13} \mathrm{C}$ values between $\mathrm{C}_{4}$ plants is lower than between $\mathrm{C}_{3}$ plants, and primarily the result of differences in bundle sheath leakage (Bowman et al. 1989). The water-use efficiency of $\mathrm{C}_{3}$ plants increases when water availability decreases, leading to ${ }^{13} \mathrm{C}$ enrichment in leaf carbon (Farquhar et al. 1982a; Farquhar et al. 1989; Lajtha and Getz 1993). High soil salinity, which reduces floral water uptake capacity, contributes up to $3 \%$ enrichment in ${ }^{13} \mathrm{C}$ of plant tissues (leaves, stems, roots) of both halophytic and non-halophytic species (Farquhar et al. 1982b; Bowman et al. 1989; Hokmabadi et al. 2005; Wei et al. 2008). Irradiance also influences foliar $\delta^{13} \mathrm{C}$ values, where higher solar irradiance is associated with ${ }^{13} \mathrm{C}$-enrichment of leaves (Ehrlinger et al. 1986). Differences in $\delta^{13} \mathrm{C}$ associated with irradiance are attributed to variation in intercellular $\mathrm{CO}_{2}$ concentration (Farquhar et al. 1982a).
The $\delta{ }^{15} \mathrm{~N}$ values of plants are determined by source nitrogen and whether nitrogen is taken up by plants directly from soil nitrogen pools or if this process is mediated by symbiotic microbes (Evans 2007; Szpak et al. 2013, Szpak 2014). A negative relationship has been observed between mean annual precipitation and the nitrogen isotopic composition of foliage (Handley et al. 1999; Amundson et al. 2003) with high foliar $\delta^{15} \mathrm{~N}$ values typical for arid environments. (Virginia and Delwiche 1982; Handley et al. 1999; van Groenigen and van Kessel 2002). Soil salinity also influences plant $\delta^{15} \mathrm{~N}$ values, with plants growing in saline soils enriched in ${ }^{15} \mathrm{~N}$ from 4 to $10 \%$ o higher than those growing in non-saline soils (Heaton 1987). The addition of ${ }^{15} \mathrm{~N}$-enriched manure, either intentionally applied to enhance agricultural plots or by animals grazing in pastures, to soils also contributes to high $\delta^{15} \mathrm{~N}$ values in plant tissues (Bogaard et al. 2007; Fraser et al. 2011; Szpak et al. 2012; Makarewicz 2014). Animal manure in pastures has been shown to increase the $\delta^{15} \mathrm{~N}$ values of pastures which is reflected in the ${ }^{15} \mathrm{~N}$-enriched tissues of animals grazing in these pastures (Makarewicz 2014).

A few studies have systematically documented variation in the underlying floral biome in the Eurasian steppe (Liu et al. 2004; Makarewicz and Tuross 2006; Zhou et al. 2006; Wittmer et al. 2010; Shishlina et al. 2012; Makarewicz 2014). Some of these studies indicate an increase in the abundance of $\mathrm{C}_{4}$ plant species with increasing aridity (Zhou et al. 2006; Wittmer et al. 2010; Wang et al. 2013). Contemporary livestock grazing on steppe pastures exhibit ${ }^{13} \mathrm{C}$ enrichment in hair keratin with increasing aridity reflecting ingestion of both $\mathrm{C}_{4}$ and water stressed $\mathrm{C}_{3}$ graze (Auerswald et al. 2012; Auerswald et al. 2009). There is also high isotopic variation in steppe floral biomes, due to local differences in soil nitrogen sources (Makarewicz 2014). Seasonality also drives nitrogen isotopic variation in pastures, with winter season pastures enriched in ${ }^{15} \mathrm{~N}$ compared to summer pastures, reflecting concentrated manure input by large herds in restricted areas (Makarewicz 2014).

\section{Contemporary environments of the northern Kazakh steppe}

The northern Kazakh steppe is a dry upland biome, encompassing the two study areas which are located in the Turgay plateau of Kostanai Oblast' (province) consisting of the broadly defined Trans-Ural Turgay steppe phytogeographic zone (Rachkovskaya and Bragina 2012; Deák et al. 2016, Fig. 1). Fescue-feather grass steppe and xerophytic forb-feather grass steppe dominate this region (Rachkovskaya and Bragina 2012; Bragina 2016) and are interspersed with several distinct vegetation communities 
Fig. 1 Location of the archeological sites of Bestamak (MBA), Kamennyi Ambar (MBA), Bolshekaragansky (MBA), and Lisakovsk (LBA)

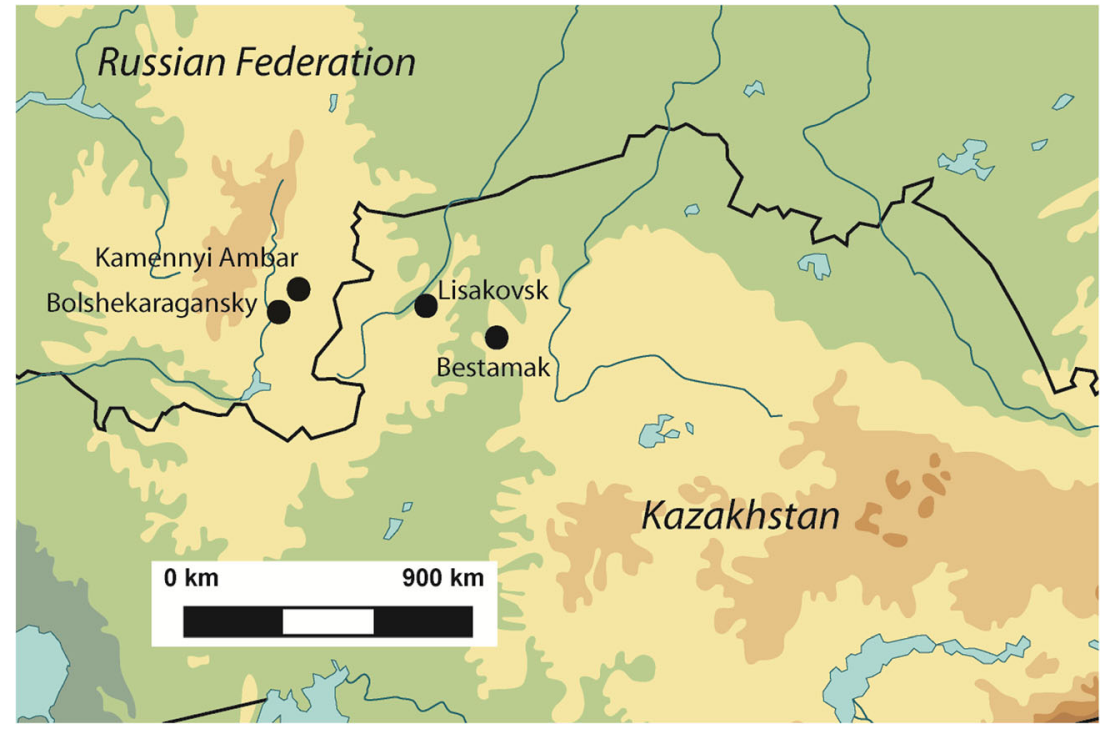

including sedge marshes, meadow steppes, and saline marshes. Sedge marshes grow in watery depressions alongside willow brushwoods, while xerophytic forbs, fescues, and grasses including sagebrush and bunchgrass are found in dry or salt marsh zones. Relic pine forests are interspersed with meadow steppes adjacent to lake terraces (Rachkovskaya and Bragina 2012). Precipitation for the Trans-Ural Turgay steppe averages $310 \mathrm{~mm}$ per year, with ca. $120 \mathrm{~mm}$ falling during the summer months (Ilyakova et al. 2015). The summer is generally dry and hot, reaching maximum temperatures of $28{ }^{\circ} \mathrm{C}$, with intermittent rain storms (Ilyakova et al. 2015). Winters are cold with average January temperature of $-18{ }^{\circ} \mathrm{C}$ and low temperatures reaching $-42{ }^{\circ} \mathrm{C}$. The study areas have slightly undulating topographic relief, often under $10 \mathrm{~m}$ in variation, yet depressions capture surface water after snowmelt and due to runoff while upland locations with slightly higher elevations are drier (De Pauw 2007).

\section{Bronze age environments}

The few paleoclimate reconstructions of the Turgay plateau are based on analyses of pollen, macro-remains preserved in peat, and spectral photometry of soils (Krementski 1997; Kremenetski et al. 1997a; Kremenetski et al. 1997b; Stobbe et al. 2015; Stobbe et al. 2016). A study by Krementeski et al. (1997a, 1997b) of a lake core from Mokhovoe Lake (Kostanai Oblast'), between the Tobol and Ubagan Rivers, exhibits a hiatus in sediment deposition between 2500 and 900 cal BCE. This hiatus corresponds with the Bronze Age and was interpreted to indicate a period of aridity (Kremenetski et al. 1997a). In contrast, recent sedimentological and palynological evidence from the site of Kamennyi Ambar in the southern Trans-Urals suggests that the climate was relatively humid, similar to the modern period, from 2400 to $1750 \mathrm{cal}$ BCE (Stobbe et al. 2015). The latter dataset is further supported by macro-remains excavated from Bronze Age settlements in the southern Trans-Urals and pollen from off-site archives for paleoenvironmental reconstruction (Stobbe et al. 2016). Off-site pollen archives are located outside of the archeological settlement but in buried soils that have been radiocarbon dated. These results suggest that the composition of vegetation has remained fairly similar between modern day and Bronze Age pollen assemblages and that these vegetation patterns may result from similar climatic conditions.

\section{Materials and methods}

We investigate the scale of Bronze Age pasture use on the Turgay plateau in part through investigation of the carbon and nitrogen isotopic composition of contemporary plants obtained from distinct vegetation communities situated near the prehistoric settlements of Bestamak and Lisakovsk. The Middle Bronze Age site of Bestamak is located near the confluence of the Buruktal and Ubagan rivers with numerous lakes dotting the landscape and the Late Bronze Age site of Lisakovsk located in the open steppe along the Tobol River. Sample units were placed to capture the diverse vegetation communities present in this region of the northern Kazakh steppe, including riverine, salt lake, marsh, elevated plateau, and grassland zones. Areas affected by anthropogenic inputs that might influence, in particular, the nitrogen isotope composition of sampled plants were avoided. This does not include manuring as part of pasture use by livestock, which could not be avoided.

Plants were sampled from a total of 37 collection units (each measuring $1 \mathrm{~m}^{2}$ ) from Bestamak and $43\left(1 \mathrm{~m}^{2}\right)$ units 
from Lisakovsk between July 30, 2014 and August 27, 2014. At Bestamak, plants were collected from 31 units in the open steppe, 4 units near rivers or streams, 1 near a saline lake, and 1 in a partially forested area. In the Lisakovsk study area, a total of 35 units were located in the open steppe, 4 near rivers, 1 next to a freshwater lake, 2 near saline lakes, and 1 unit in a partially forested area. Every plant species within each unit was collected in duplicate and identified to genus and, when possible, to species alongside Russian language folk taxonomy by a trained botanist (Supplementary Tables 1 and 2). While in the field plant species were counted within each sampling unit, and these counts were used to calculate the

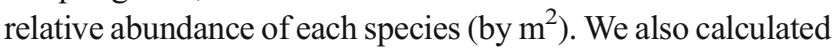
the distribution of $\mathrm{C}_{3}$ and $\mathrm{C}_{4}$ plants by unit and plant functional types. Plant functional types included grasses, flowering non-woody plants, trees, and shrubs. Two examples of each plant species were collected from every unit, and plants were placed on moisture extraction paper after collection.

A total of 88 plant specimens, representing 3 functional types and 29 species, were analyzed for carbon and nitrogen isotopes from 10 collection units (each measuring $1 \mathrm{~m}^{2)}$ around the site of Bestamak. Collection units were placed in the open steppe $(n=7)$, at the edge of a marsh $(n=1)$, near a salt lake $(n=1)$, and on the lower bank of the Ubagan River $(n=1)$ (Fig. 2). In the Lisakovsk study area, 28 modern plants consisting of 20 species that represent three functional types were analyzed from four collection units. Collection units were located in the open steppe $(n=2)$, at the lower bank of the Tobol River $(n=1)$, and at the edge of a saline lake $(n=1)$ (Fig. 2). Plants were washed with ultra-pure deionized water to eliminate superficial contaminants including soil or dung and then oven dried at $60{ }^{\circ} \mathrm{C}$. Plants were then subsampled and homogenized by combining leaf, stem, and seed parts. All plant parts that were above the soil were included in the isotopic study as these are all ingested by livestock. Samples were analyzed for $\delta^{13} \mathrm{C}$ and $\delta^{15} \mathrm{~N}$ in continuous flow mode on a Eurovector elemental analyzer interfaced with a GV Instruments IsoPrime isotope ratio mass spectrometer at the Boston University Stable Isotope Laboratory. The analytical error for $\delta^{13} \mathrm{C}$ and $\delta^{15} \mathrm{~N}$ measurements from the same sample, was determined at $\pm 0.2 \%$ o $(1 \sigma)$, or better. Percent abundance of $\mathrm{C}_{4}$ plants was calculated for each unit as the number of $\mathrm{C}_{4}$ plants per unit divided by the number of total plants per unit. Percent abundance, of $\mathrm{C}_{4}$ plants by study area, was calculated for each $1 \mathrm{~m}^{2}$, then added together and divided by the total number of square meters.

Isoscapes are spatially defined predictions of isotope ratios computed for a given landscape according to known isotopefractionation processes and environmental factors that influence isotope values (Bowen 2010: West et al. 2010). Isoscapes help constrain the range of isotopic variation with a given area and, consequently, are a useful means for exploring spatially derived variation in the isotopic composition of animals moving within a landscape (Wunder 2010). Here, we constructed isoscapes by mapping the results of isotopic analyses of modern plants collected from the contemporary landscape. Plant collection units were geo-referenced and assigned $\delta^{13} \mathrm{C}$ values based on the abundance of plant functional types. The $\delta^{13} \mathrm{C}$ composition of vegetation in units with measured isotope values was calculated by weighting the $\delta^{13} \mathrm{C}$ value for each plant species according to the abundance of each species. Units lacking measured isotope values were assigned a carbon isotope value calculated from an average value derived from each plant functional type multiplied by the percent abundance of that group in each unit. Average values of plant functional types were calculated separately for grasses, flowering non-woody plants, and other plants. Carbon isotope values were adjusted by $+1.5 \%$ for the Suess Effect (Keeling 1979; Yakir 2011). The $\delta^{15} \mathrm{~N}$ composition of vegetation was estimated in the same way, using measured values to estimate values by unit and plant functional type abundance. Isoscapes were made in ArcGIS Pro ver. 2.1 by interpolating carbon, or nitrogen, values using a spline function with barriers. In the spline interpolation method, a raster surface is created from points using a minimum curvature spline technique. Barriers were created from polygons of rivers, lakes, and ponds. A minimum curvature surface both honors the input data and applies a deformation to each cell calculated by comparing a

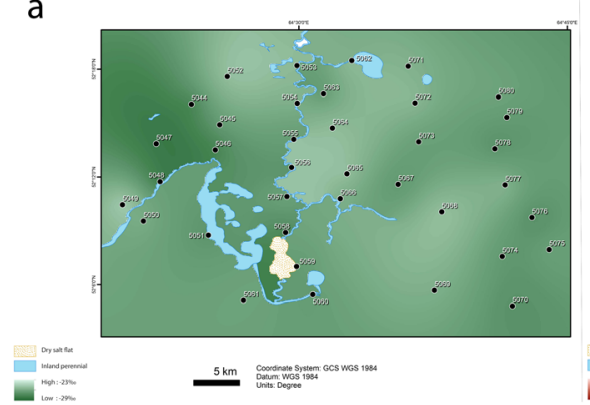

b

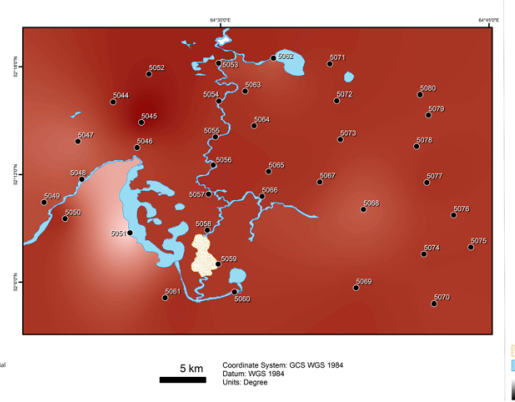

C

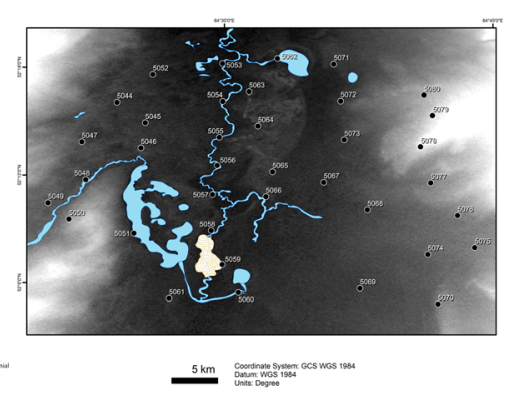

Fig. 2 Bestamak study area. a $\delta^{13} \mathrm{C}$ isoscape. b $\delta^{15} \mathrm{~N}$ isoscape. c Digital elevation model (ArcGIS Pro ver. 2.1) 
the weighted sum of 12 neighboring cells with the current value of a target cell to calculate a new value for the target cell (Terzopoulos 1988).

The stable isotope ratios of bone collagen record dietary intake (DeNiro and Epstein 1978; Tieszen et al. 1983) and geographical information, which occurs as carbon and nitrogen isotope variation in the underlying floral biome is integrated into the tissues of herbivores as they graze on vegetation. The isotopic composition of bone collagen reflects a "lifetime average" of dietary intake over several years (Hedges et al. 2007). Previously published faunal collagen isotope data was compiled from sites located in northern Kazakhstan (Ventresca Miller et al., 2014a; MotuzaiteMatuzeviciute et al. 2015) and the southern Trans-Urals (Hanks et al. 2018; Privat 2004). The isotopic composition of livestock, including horse, cattle, sheep, and goat, were compared from three Middle Bronze Age sites and one Late Bronze Age site in the region. Average $\delta^{13} \mathrm{C}$ and $\delta^{15} \mathrm{~N}$ values were compared using an analysis of variance coupled with a Tukey's post-hoc test to determine the statistical significance of differences between plants by unit and livestock species by site (R development core team). We employ $\delta^{13} \mathrm{C}$ and $\delta^{15} \mathrm{~N}$ isoscape models as a heuristic device to infer how ancient livestock taxa may have exploited different vegetation communities in the steppe landscape.

\section{Results}

\section{The floral base of the foodweb}

The modern floral biome is diverse in both study areas with a wide range of species identified and spatial variation in the isotopic composition of plants. Plant samples collected from the Bestamak study area ( $n=37$ units) included 52 species identified, from 4 plant functional types, with the number of species per $1 \mathrm{~m}^{2}$ unit ranging from 2 to 15 (average of 6.1 species/unit). Within the Lisakovsk study area, 43 collection units were investigated, and the number of plant species per $1 \mathrm{~m}^{2}$ collection unit ranged from 2 to 13 , with an average of 6.8 species per unit. The Bestamak study area supported an equal abundance of grasses $(47.6 \%)$ and flowering nonwoody plants $(46.7 \%)$, with $2.6 \%$ shrubs, and less than $2.9 \%$ trees and unidentified species. Similarly, the Lisakovsk study area had equal percentages of grasses $(48.6 \%)$ and flowering non-woody plants (49.8\%), with fewer than $2 \%$ trees, shrubs, and unidentified plants. Percentages of plant functional types were calculated based on the total number of plant types counted in each unit, which were then added together for each area (Bestamak or Lisakovsk). Comparatively, a higher number of plant species were identified in the vicinity of Lisakovsk $(n=82)$ than Bestamak $(n=$ 52) (Supplementary Table 1).
The absolute number of $\mathrm{C}_{4}$ plants identified in both study areas is low, as is the relative abundance of $\mathrm{C}_{4}$ plants. Of the 88 plants analyzed from vegetation units at Bestamak, four taxa are $\mathrm{C}_{4}$ plants, and all are grasses (three Cleistogenes spp. and one Eremopyrum spp.). Within vegetation units at Lisakovsk, 28 plants were analyzed, and only two taxa were $\mathrm{C}_{4}$ plants, one was a flowering non-woody plant (Koeleria gracilis) and the other a shrub (Euphorbia spp.). The relative abundance (density per square meter) of $\mathrm{C}_{4}$ plants, of those analyzed, was low at Bestamak and Lisakovsk at 0.04 and $0.1 \%$, respectively.

The range of isotopic variation among plants at both sites is large and comparable with other steppe regions (e.g., Makarewicz and Tuross 2006; Shishlina et al. 2012). In the vicinity of Bestamak, $\mathrm{C}_{3}$ plants $(n=84)$ exhibited $\delta^{13} \mathrm{C}$ values ranging from -30.0 to $-23.6 \%$ and a wide range of $\delta^{15} \mathrm{~N}$ values from -2.4 to $9.9 \%$ (Tables 1 and 3 ). In the same zone, $\mathrm{C}_{4}$ plants $(n=4)$ yielded $\delta^{13} \mathrm{C}$ values ranging from -15.2 to $14.5 \%$ with $\delta^{15} \mathrm{~N}$ values from -1.6 to $3.4 \%$. Floral growth in sample units located close to water sources, either saline or fresh, were $3.4 \%$ o higher on average in $\delta^{15} \mathrm{~N}$ relative to units located at higher elevations. Average $\delta^{15} \mathrm{~N}$ values were higher by ca. $3 \%$ for units located outside of a small village that is currently occupied (distance from settlement $=0.8 \mathrm{~km}$ for 5048, $2 \mathrm{~km}$ for 5049) and a unit (3067) situated $50 \mathrm{~m}$ from a plowed field, when compared with units located in the open steppe. Significant differences were identified in average $\delta^{15} \mathrm{~N}$ values between all units (ANCOVA, $p=3.09 \times 10^{-12}$; Supplemental Table 2) and between units; unit 5051 was removed due to its small sample size (ANCOVA, $p=1.68 \times$ $\left.10^{-9}\right)$. Collection unit $5051(n=2)$ was located in a marshy area and exhibited the highest nitrogen isotope values (mean $\delta^{15} \mathrm{~N}=9.3 \%$ ) and was enriched in ${ }^{15} \mathrm{~N}$ by 4.9 to $9.2 \%$ relative to other units. Units with $\delta^{15} \mathrm{~N}$ values ranging from 3.3 to $4.4 \%$ were located in areas close to the river (5053) and salt lake (5062), as well as in areas of anthropogenic activity near towns (5048 and 5049) and near a plowed field (5067). Units with the lowest $\delta^{15} \mathrm{~N}$ values, ranging from -0.1 to $1.6 \%$ o were located in the open steppe $(5044,5045,5047$, and 5052). Units were combined into three vegetation communities including the open steppe (OS), areas of anthropogenic activity (AA) and riverine, salt lake, and marsh (RSL). Significant differences in $\delta^{15} \mathrm{~N}$ values were identified between the plants in the open steppe and those in areas of anthropogenic activity and near water (ANCOVA, $p=1.41 \times 10^{-11}$; Supplemental Table 2). No statistically significant isotopic variation was evident in carbon isotope values between units or vegetation communities (Supplemental Table 2).

In the vicinity of the Lisakovsk site, modern $\mathrm{C}_{3}$ plants $(n=$ 26) had measured $\delta^{13} \mathrm{C}$ values ranging from -30.7 to $-25.1 \%$ o with a wide range of $\delta^{15} \mathrm{~N}$ values from 1.0 to $8.2 \%$ (Table 2). Comparatively, $\mathrm{C}_{4}$ plants $(n=2)$ had measured $\delta^{13} \mathrm{C}$ values ranging from -14.7 to $-13.8 \%$ and $\delta^{15} \mathrm{~N}$ values from 8.4 to 
Table 1 Carbon and nitrogen isotope values of plant species from the Bestamak study area

\begin{tabular}{|c|c|c|c|c|}
\hline Sample & Unit & Plant species & $\delta^{13} \mathrm{C}$ & $\delta^{15} \mathrm{~N}$ \\
\hline 6307 & 5044 & Artemisia pontica $\mathrm{L}$. & -28.47 & 1.78 \\
\hline 6308 & 5044 & Stipa capillata $\mathrm{L}$. & -24.71 & 0.82 \\
\hline 6309 & 5044 & Agropyron pectinatum (Bieb.) Beauv. & -26.61 & 2.14 \\
\hline 6310 & 5044 & Hieracium spp. & -27.61 & 2.02 \\
\hline 6311 & 5044 & Not available & -29.16 & 2.45 \\
\hline 6312 & 5044 & Festuca valesiaca Gaudin. & -27.43 & 0.80 \\
\hline 6313 & 5044 & Tragopogon orientalis $\mathrm{L}$. & -28.47 & 3.00 \\
\hline 6314 & 5044 & Dianthus borbasii Vandas & -26.82 & 1.77 \\
\hline 6315 & 5044 & Familia Poaceae & -27.79 & 2.09 \\
\hline 6316 & 5044 & Potentilla erecta (L.) Raeusch. & -27.03 & -0.37 \\
\hline 6317 & 5044 & Koeleria cristata $\mathrm{L}$. & -26.51 & 0.69 \\
\hline 6318 & 5044 & Artemisia spp. & -30.01 & 3.34 \\
\hline 6320 & 5044 & Unknown & -28.38 & 0.99 \\
\hline 6321 & 5044 & Carex spp. & -26.96 & 0.24 \\
\hline 6322 & 5045 & Artemisia pontica $\mathrm{L}$. & -27.38 & -0.25 \\
\hline 6323 & 5045 & Stipa capillata $\mathrm{L}$. & -25.99 & -0.40 \\
\hline 6324 & 5045 & Koeleria cristata $\mathrm{L}$. & -25.06 & 0.77 \\
\hline 6325 & 5045 & Tragopogon orientalis $\mathrm{L}$. & -26.95 & 0.47 \\
\hline 6326 & 5045 & Agropyron pectinatum (Bieb.) Beauv. & -28.33 & -1.12 \\
\hline 6327 & 5045 & Achillea nobilis $\mathrm{L}$. & -29.01 & 0.17 \\
\hline 6328 & 5045 & Potentilla erecta (L.) Raeusch. & -26.79 & -0.73 \\
\hline 6329 & 5045 & Familia Asteraceae & -23.63 & 1.63 \\
\hline 6330 & 5045 & Cleistogenes spp. & -14.54 & -1.55 \\
\hline 6331 & 5045 & Artemisia spp. & -28.80 & 1.02 \\
\hline 6332 & 5045 & Medicago falcata $\mathrm{L}$. & -25.89 & -2.42 \\
\hline 6333 & 5045 & Artemisia spp. & -26.33 & 1.27 \\
\hline 6337 & 5047 & Artemisia pontica L. & -28.31 & 7.82 \\
\hline 6338 & 5047 & Achillea nobilis L. & -29.87 & -1.60 \\
\hline 6339 & 5047 & Koeleria cristata L. & -28.04 & -0.88 \\
\hline 6340 & 5047 & Familia Poaceae & -27.54 & 0.01 \\
\hline 6341 & 5047 & Poa pratensis $\mathrm{L}$. & -25.30 & -0.51 \\
\hline 6342 & 5047 & Achillea nobilis L. & -27.95 & -1.16 \\
\hline 6343 & 5047 & Stipa spp. & -28.74 & -0.72 \\
\hline 6344 & 5047 & Agropyron pectinatum (Bieb.) Beauv. & -28.69 & -1.13 \\
\hline 6345 & 5047 & Centaurea scabiosa $\mathrm{L}$. & -29.72 & -1.92 \\
\hline 6346 & 5047 & Potentilla erecta (L.) Raeusch. & -27.14 & -0.52 \\
\hline 6347 & 5047 & Artemisia spp. & -29.77 & -1.63 \\
\hline 6348 & 5047 & Hieracium spp. & -28.57 & 2.53 \\
\hline 6349 & 5047 & Medicago falcata $\mathrm{L}$. & -26.89 & -1.25 \\
\hline 6350 & 5048 & Agropyron pectinatum (Bieb.) Beauv. & -27.53 & 3.49 \\
\hline 6351 & 5048 & Artemisia campestris L. & -27.90 & 4.47 \\
\hline 6352 & 5048 & Festuca valesiaca Gaudin. & -26.41 & 1.65 \\
\hline 6353 & 5048 & Artemisia pontica $\mathrm{L}$. & -29.61 & 3.31 \\
\hline 6354 & 5048 & Achillea nobilis L. & -27.89 & 6.03 \\
\hline 6355 & 5048 & Hieracium $L$ & -27.78 & 5.62 \\
\hline 6356 & 5048 & Hieracium L & -27.78 & 0.78 \\
\hline 6357 & 5049 & Lepidium crassifolium Waldst. et Kit. & -23.93 & 9.96 \\
\hline 6359 & 5049 & Stipa capillata L. & -25.95 & 1.28 \\
\hline 6360 & 5049 & Artemisia campestris L. & -28.25 & 4.25 \\
\hline
\end{tabular}


Table 1 (continued)

\begin{tabular}{|c|c|c|c|c|}
\hline Sample & Unit & Plant species & $\delta^{13} \mathrm{C}$ & $\delta^{15} \mathrm{~N}$ \\
\hline $6360 \mathrm{~b}$ & 5049 & Unknown & -27.95 & 3.93 \\
\hline 6361 & 5049 & Unknown & -25.15 & 7.66 \\
\hline 6364 & 5049 & Cleistogenes spp. & -14.75 & 1.77 \\
\hline 6365 & 5049 & Agropyron pectinatum (Bieb.) Beauv. & -27.70 & 2.22 \\
\hline 6366 & 5049 & Hieracium L & -28.46 & 2.71 \\
\hline 6367 & 5049 & Dianthus borbasii Vandas & -24.86 & 4.71 \\
\hline 6368 & 5049 & Stipa spp. & -25.46 & 1.65 \\
\hline 6369 & 5049 & Unknown & -28.30 & 0.44 \\
\hline 6376 & 5051 & Ephedra equisetina Bunge & -26.91 & 9.79 \\
\hline 6377 & 5051 & Phragmites communis (Cav.) Trin. ex Steud. & -24.26 & 8.88 \\
\hline 6378 & 5052 & Festuca valesiaca Gaudin. & -25.54 & -0.23 \\
\hline 6379 & 5052 & Agropyron pectinatum (Bieb.) Beauv. & -28.36 & -0.67 \\
\hline 6380 & 5052 & Achillea nobilis L. & -27.98 & 1.29 \\
\hline 6381 & 5052 & Artemisia campestris L. & -27.44 & 0.68 \\
\hline 6382 & 5052 & Artemisia pontica $\mathrm{L}$. & -29.28 & 0.07 \\
\hline 6383 & 5052 & Cleistogenes spp. & -14.63 & 0.20 \\
\hline 6384 & 5052 & Unknown & -27.10 & 3.11 \\
\hline 6385 & 5052 & Lepidium crassifolium Waldst. et Kit. & -28.80 & 0.67 \\
\hline 6390 & 5053 & Festuca spp. & -27.14 & 1.63 \\
\hline 6391 & 5053 & Artemisia pontica $\mathrm{L}$. & -28.77 & 3.63 \\
\hline 6392 & 5053 & Stipa capillata $\mathrm{L}$. & -26.24 & 3.50 \\
\hline 6393 & 5053 & Salvia stepposa D.-Sch. & -26.64 & 3.79 \\
\hline 6394 & 5053 & Artemisia pontica $\mathrm{L}$. & -29.62 & 3.92 \\
\hline 6440 & 5062 & Poa pratensis $\mathrm{L}$. & -25.56 & 4.67 \\
\hline 6441 & 5062 & Galium verum $\mathrm{L}$. & -29.23 & 4.95 \\
\hline 6441 & 5062 & Galium verum $\mathrm{L}$. & -29.54 & 4.90 \\
\hline 6442 & 5062 & Artemisia campestris L. & -27.67 & 4.74 \\
\hline 6443 & 5062 & Euphorbia esula L. & -27.13 & 5.03 \\
\hline 6444 & 5062 & Festuca valesiaca Gaudin. & -27.09 & 4.01 \\
\hline 6445 & 5062 & Festuca valesiaca Gaudin. & -25.78 & 4.99 \\
\hline 6446 & 5062 & Stipa capillata $\mathrm{L}$. & -24.40 & 3.45 \\
\hline 6447 & 5062 & Eremopyrum spp. & -15.16 & 3.44 \\
\hline 6448 & 5062 & Agropyrum repens (L.) P.B. & -24.97 & 4.18 \\
\hline 6476 & 5067 & Festuca valesiaca Gaudin. & -25.47 & 2.78 \\
\hline 6477 & 5067 & Hieracium $\mathrm{sp}$. & -25.02 & 4.04 \\
\hline 6478 & 5067 & Limonium gmelinii (Willd.) Kuntze & -26.98 & 3.24 \\
\hline 6479 & 5067 & Artemisia pontica $\mathrm{L}$. & -25.73 & 1.45 \\
\hline 6480 & 5067 & Artemisia pontica $\mathrm{L}$. & -28.96 & 3.42 \\
\hline 6481 & 5067 & Agropyrum repens (L.) P.B. & -25.75 & 4.77 \\
\hline
\end{tabular}

9.3\%o (Tables 2 and 4). No significant differences were evident between units, although high mean $\delta^{13} \mathrm{C}$ values ranging from 28.6 to $-26.1 \%$ o were consistently identified in the open steppe and near the river, while the lowest plant carbon values were from the unit located at the edge of the saline lake (Fig. 3). Isotopic variation between collection units at Lisakovsk $(n=$ 4 ) indicates that significant differences were identified in average $\delta^{15} \mathrm{~N}$ values between unit 5013 and the other units
(ANCOVA, $p=1.86 \times 10^{-4}$ ), but no statistically significant isotopic variation was evident in carbon isotope values (ANCOVA, $p=0.59$; Table 3). Unit 5013 has a significantly lower average nitrogen isotope composition than other units by $3.2 \%$ (Table 3 ). The remaining collection units had average nitrogen values ranging from 5.8 to $7.5 \%$ and were located in open steppe $(5019,5020)$ and near the Tobol River (5008). 
Table 2 Carbon and nitrogen isotope values of plant species from the Lisakovsk study area

\begin{tabular}{|c|c|c|c|c|}
\hline ASIL \# & Unit & Plant Species & $\delta^{13} \mathrm{C}$ & $\delta^{15} \mathrm{~N}$ \\
\hline 2086 & 5008 & Agropyron pectinatum (Bieb.) Beauv. & -25.44 & 4.94 \\
\hline 2087 & 5008 & Artemisia pontica $\mathrm{L}$. & -30.19 & 6.31 \\
\hline 2088 & 5008 & Lactuca tatarica (L.). C.A. Mey & -25.09 & 6.47 \\
\hline 2089 & 5008 & Astragalus arenarius L. & -28.84 & 7.82 \\
\hline 2090 & 5008 & Elymus giganteus $\mathrm{L}$. & -27.77 & 4.92 \\
\hline 2091 & 5008 & Agropyron pectinatum (Bieb.) Beauv. & -25.58 & 4.11 \\
\hline 2178 & 5020 & Festuca valesiaca Gaudin. & -28.38 & 5.06 \\
\hline 2179 & 5020 & Koeleria cristata L. & -29.75 & 6.30 \\
\hline 2180 & 5020 & Artemisia pontica $\mathrm{L}$. & -27.79 & 8.23 \\
\hline 2176 & 5019 & Medicago falcata $\mathrm{L}$. & -26.96 & 5.91 \\
\hline 2177 & 5019 & Artemisia pontica $\mathrm{L}$. & -25.23 & 7.11 \\
\hline 2129 & 5013 & Juncus compressus Jacq. & -29.16 & 2.07 \\
\hline 2130 & 5013 & Plantago cornuti Gouan & -29.22 & 1.00 \\
\hline 2130 & 5013 & Plantago cornuti Gouan & -30.16 & 1.60 \\
\hline 2131 & 5013 & Triglochin maritima $\mathrm{L}$. & -27.99 & 2.07 \\
\hline 2131 & 5013 & Triglochin maritima $\mathrm{L}$. & -26.73 & 3.49 \\
\hline 2132 & 5013 & Salicornia europaea L. & -28.40 & 4.45 \\
\hline 2133 & 5013 & Chenopodium album L. & -27.41 & 5.79 \\
\hline 2134 & 5013 & Calamagrostis epigeios L. Roth. & -28.37 & 1.96 \\
\hline 2134 & 5013 & Calamagrostis epigeios L. Roth. & -28.27 & 2.52 \\
\hline 2135 & 5013 & Phragmites australis (Cav.) Trin. ex Steud. (=Phragmites communis) & -27.21 & 4.88 \\
\hline 2136 & 5013 & Puccinellia distans $\mathrm{L}$. & -29.67 & 2.39 \\
\hline 2136 & 5013 & Puccinellia distans $\mathrm{L}$. & -30.73 & 2.81 \\
\hline 2137 & 5013 & Puccinellia tenuissima Litv. ex V Krecz. & -26.85 & 3.66 \\
\hline 2138 & 5013 & Limonium gmelinii (Willd.) Kuntze & -27.91 & 3.73 \\
\hline 2139 & 5013 & Chenopodium spp. & -30.60 & 1.44 \\
\hline 2181 & 5020 & Koeleria gracilis & -13.79 & 9.31 \\
\hline 2182 & 5020 & Euphorbia spp. & -14.69 & 8.37 \\
\hline
\end{tabular}

The isoscapes indicate differences in the distribution of both carbon and nitrogen isotopes between the two study areas, with Lisakovsk exhibiting a more homogeneous plant carbon and nitrogen isotope compositions than Bestamak (Fig. 3; Tables 3 and 4). The Bestamak isoscape indicates greater variation in the spatial distribution of carbon isotope ratios, with plants located in marshy areas and near the salt lake enriched in ${ }^{13} \mathrm{C}$ relative to plants located in the steppe and near the river. Comparatively, lower $\delta^{13} \mathrm{C}$ values in the Lisakovsk isoscape suggest that the area was wetter and had less saline soils. The nitrogen isoscape at Bestamak has a wide spread of values, with higher values in saline and marsh areas. The $\delta^{15} \mathrm{~N}$ isoscape at Lisakovsk indicates higher nitrogen values in open steppe $(\sim 7 \%$ ) and near the river $(\sim 5 \%)$, with the lowest nitrogen values near the saline lake $(\sim 3 \%$ o). Plants located in the open steppe at Lisakovsk are enriched in ${ }^{15} \mathrm{~N}$ by 4.9 to $7.1 \%$ relative to those at Bestamak.

\section{Isotopic values of ancient livestock}

Domesticated livestock, including horses, cattle, sheep, and goats were recovered from the Bronze Age sites of Kamennyi Ambar, Bolshekaragansky, Bestamak and Lisakovsk. Different livestock taxa from these sites yield similar average values with no significant differences in average $\delta^{13} \mathrm{C}$ and $\delta^{15} \mathrm{~N}$ values by taxa (Fig. 4; Table 5; ANCOVA, $\left.\delta^{13} \mathrm{C} p=0.17, \delta^{15} \mathrm{~N} p=0.55\right)$. Inter-species carbon isotopic distinctions were visible across sites where horses were depleted in ${ }^{13} \mathrm{C}$ on average by 0.7 to $1.5 \%$ relative to cattle and by 1.2 to $2.3 \%$ orelative to sheep/goat. Kamennyi Ambar livestock exhibited the widest range of $\delta^{13} \mathrm{C}$ values from -20.8 to $-17.1 \%$, while at Bolshekaragansky, $\delta^{13} \mathrm{C}$ values ranged from -19.7 to $-18.5 \%$. At Bestamak, $\delta^{13} \mathrm{C}$ values ranged from -20.0 to $-17.7 \%$, and at Lisakovsk, livestock had $\delta^{13} \mathrm{C}$ values ranging from -20.8 to $-18.7 \%$. At Lisakovsk (ANCOVA, $p=1.28 \times 10^{-5}$ ), a significant $0.9 \%$ depletion in ${ }^{13} \mathrm{C}$ is visible in horses relative to cattle (Tukey post-hoc HSD, 

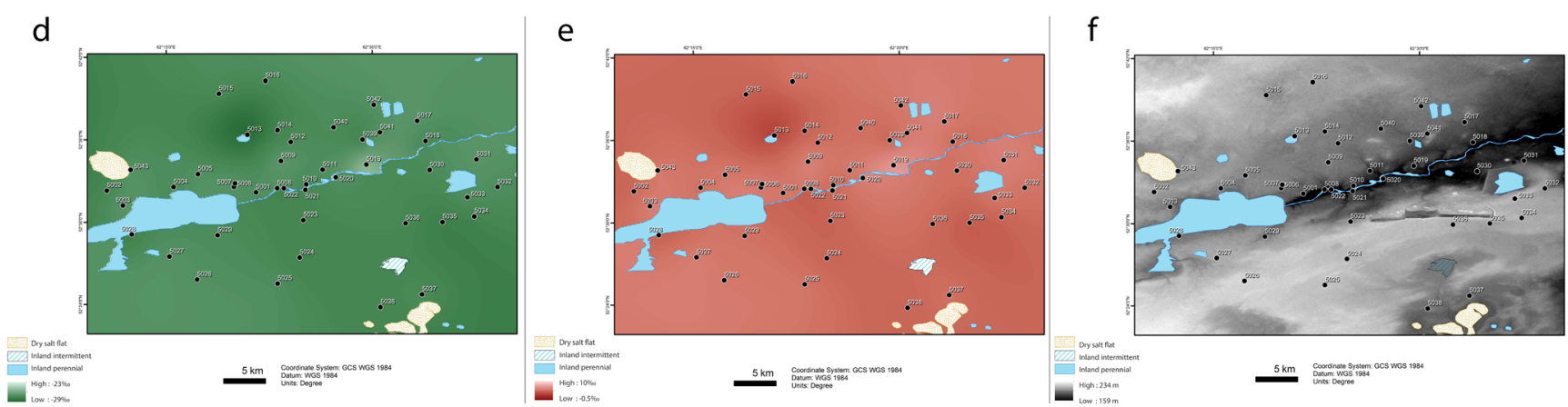

Fig. 3 Lisakovsk study area. $\mathbf{d} \delta^{13} \mathrm{C}$ isoscape. e $\delta^{15} \mathrm{~N}$ isoscape. f Digital elevation model (ArcGIS Pro ver. 2.1)

$p=0.0018)$ and a $1.2 \%$ depletion relative to sheep/goat (Tukey post-hoc HSD, $p<0.0005$ ). Differences between species was also significant at Kamennyi Ambar, (ANCOVA, $p=0.0012$ ); however, significant differences were identified only between sheep/goat and horses, not horses and cattle (Table 5). Horses were depleted in ${ }^{13} \mathrm{C}$, on average by $1.1 \%$ o compared to cattle (Tukey post-hoc HSD, $p=0.65$ ) and by $1.9 \%$ relative to sheep/goat (Tukey post-hoc HSD, $p=0.008$ ).

No significant nitrogen isotopic differences were visible between taxa or between sites. Horses were depleted in ${ }^{15} \mathrm{~N}$ relative to cattle at all sites, on average from 0.7 to $2.2 \%$, and horses were depleted in ${ }^{15} \mathrm{~N}$ by 0.8 to $2.8 \%$ o compared to sheep/goat. Kamennyi Ambar livestock exhibited $\delta^{15} \mathrm{~N}$ values from 3.2 to $9.8 \%$ and from $\delta^{13} \mathrm{C}$ values ranging from 4.7 to $6.9 \%$ at. A similarly low range of nitrogen isotopic variation was visible at Lisakovsk, with $\delta^{15} \mathrm{~N}$ values ranging from 4.3 to $8.3 \%$. At Bolshekaragansky, livestock exhibit $\delta^{15} \mathrm{~N}$ values ranging from 4.7 to $6.9 \%$, while at Bestamak, $\delta^{15} \mathrm{~N}$ values range from 6.2 to $8.4 \%$. No significant differences were evident in nitrogen values between species at Kamennyi Ambar (ANCOVA, $p=0.66$ ) or Lisakovsk (ANCOVA, $p=0.65$ ). Comparatively, livestock from Kamennyi Ambar had a wider range of carbon and nitrogen isotope values than those from Lisakovsk (Table 4; Fig. 4).

\section{Discussion}

\section{Sources of variation in the isotopic composition of steppe vegetation}

There is a strong relationship between vegetation community type (e.g., sedge marshes, saline marshes, and meadow steppes) and plant carbon and nitrogen isotopic compositions. High $\delta^{13} \mathrm{C}$ values in plants growing in saline marshes are likely driven by high soil salinity. The introduction of salts to soil water sources results in stomatal closure; thus, the partial ${ }^{12} \mathrm{CO}_{2}$ pressure in the plant decreases forcing it to assimilate more ${ }^{13} \mathrm{CO}_{2}$, increasing the ${ }^{13} \mathrm{C}$ composition of the newly formed plant tissue (Farquhar et al. 1982; van Groenigen and van Kessel 2002). It is unclear how salt concentrations affect plant nutrient nitrogen in the soil (Heaton 1987). High $\delta^{15} \mathrm{~N}$ values in saline areas could reflect the effects of denitrification and microbial mineralization, which produce ${ }^{15} \mathrm{~N}$-enrichment of the remaining nitrate (Heaton 1987; Cloern et al. 2002; van Groenigen and van Kessel 2002).

Low $\delta^{13} \mathrm{C}$ values and high $\delta^{15} \mathrm{~N}$ values, averaging -27.7 and 3.3\%o respectively, characterize sedge marshes located near lakes and rivers. Low $\delta^{13} \mathrm{C}$ values of sedge plants reflect high water availability and increased stomatal conductance.

Table 3 Plants by collection unit for the Bestamak Study Area (*values adjusted by $+1.5 \%$ )

\begin{tabular}{|c|c|c|c|c|c|c|c|c|c|c|c|c|c|}
\hline \multirow[b]{2}{*}{ Unit } & \multicolumn{4}{|c|}{$\delta^{13} \mathrm{C}(\% \circ)^{*}$} & \multicolumn{4}{|c|}{$\delta^{13} \mathrm{C}(\% o)$} & \multicolumn{4}{|c|}{$\delta^{15} \mathrm{~N}(\% \circ)$} & \multirow[b]{2}{*}{ Location } \\
\hline & Min & Max & Mean & $1 \sigma$ & Min & Max & Mean & $1 \sigma$ & Min & Max & Mean & $1 \sigma$ & \\
\hline 5044 & -28.5 & -23.2 & -26.1 & 1.3 & -30.0 & -24.7 & -27.6 & 1.3 & -0.4 & 3.3 & 1.6 & 1.1 & Steppe \\
\hline 5045 & -27.5 & -13.0 & -24.2 & 3.8 & -29.0 & -14.5 & -25.7 & 3.8 & -2.4 & 1.6 & -0.1 & 1.2 & Steppe \\
\hline 5047 & -28.4 & -23.8 & -26.7 & 1.3 & -29.9 & -25.3 & -28.2 & 1.3 & -1.9 & 7.8 & -0.1 & 2.6 & Steppe \\
\hline 5048 & -28.1 & -26.4 & -26.3 & 0.9 & -29.6 & -27.9 & -27.8 & 0.9 & 0.8 & 6.0 & 3.6 & 1.9 & Near town \\
\hline 5049 & -27.0 & -13.3 & -24.2 & 3.8 & -28.5 & -14.8 & -25.7 & 3.8 & 0.4 & 10.0 & 3.4 & 2.9 & Near town \\
\hline 5051 & -25.4 & -22.8 & -24.1 & 1.9 & -26.9 & -24.3 & -25.6 & 1.9 & 8.9 & 9.8 & 9.3 & 0.6 & Marsh \\
\hline 5052 & -27.8 & -13.1 & -24.6 & 4.8 & -29.3 & -14.6 & -26.1 & 4.8 & -0.7 & 3.1 & 0.6 & 1.2 & Steppe \\
\hline 5053 & -28.1 & -24.7 & -26.2 & 1.5 & -29.6 & -26.2 & -27.7 & 1.5 & 1.6 & 3.9 & 3.3 & 0.9 & Along River \\
\hline 5062 & -28.0 & -13.7 & -24.2 & 4.1 & -29.5 & -15.2 & -25.7 & 4.1 & 3.4 & 5.0 & 4.4 & 0.6 & Adjacent to Salt Lake \\
\hline 5067 & -27.5 & -23.5 & -24.8 & 1.4 & -29.0 & -25.0 & -26.3 & 1.4 & 1.4 & 4.8 & 3.3 & 1.1 & Near plowed field \\
\hline
\end{tabular}


Table 4 Plants by collection unit for the Lisakovsk Study Area (*values adjusted by $+1.5 \%$ )

\begin{tabular}{|c|c|c|c|c|c|c|c|c|c|c|c|c|c|}
\hline \multirow[b]{2}{*}{ Unit } & \multicolumn{4}{|c|}{$\delta^{13} \mathrm{C}(\% o)^{*}$} & \multicolumn{4}{|c|}{$\delta^{13} \mathrm{C}(\% \circ)$} & \multicolumn{4}{|c|}{$\delta^{15} \mathrm{~N}(\% \circ)$} & \multirow[b]{2}{*}{ Location } \\
\hline & Min & Max & Mean & $1 \sigma$ & Min & Max & Mean & $1 \sigma$ & Min & Max & Mean & $1 \sigma$ & \\
\hline 5008 & -28.7 & -23.6 & -25.7 & 2.1 & -30.2 & -25.1 & -27.2 & 2.1 & 4.1 & 7.8 & 5.8 & 1.4 & Edge of Tobol River \\
\hline 5013 & -29.2 & -25.2 & -27.1 & 1.3 & -30.7 & -26.7 & -28.6 & 1.3 & 1.0 & 5.8 & 2.9 & 1.4 & Edge of Saline Lake \\
\hline 5019 & -25.5 & -23.7 & -24.6 & 1.2 & -27.0 & -25.2 & -26.1 & 1.2 & 5.9 & 7.1 & 6.5 & 0.8 & Steppe \\
\hline 5020 & -28.3 & -12.3 & -21.4 & 7.9 & -29.8 & -13.8 & -22.9 & 7.9 & 5.1 & 9.3 & 7.5 & 1.7 & Steppe \\
\hline
\end{tabular}

Previous research has demonstrated that plants from fresh water marshes are depleted in ${ }^{13} \mathrm{C}$ relative to salt marsh growth (Tieszen 1994; van Groenigen and van Kessel 2002). The water-use efficiency of $\mathrm{C}_{3}$ plants increases as water availability decreases, as stomata conductance regulates the loss of water by transpiration; consequently, plants located in areas of abundant freshwater should have lower $\delta^{13} \mathrm{C}$ values than those in drier areas (Farquhar et al. 1982a; Farquhar et al. 1989; Lajtha and Getz 1993). Plants are enriched in ${ }^{15} \mathrm{~N}$ in wet locations and topographic depressions that provide moisture sinks, relative to drier areas (Handley et al. 1999). In locations where water accumulates, denitrification rates are highest and are related to greater $\mathrm{N}$ mineralization, resulting in $\mathrm{N}$ losses from the ecosystem and ${ }^{15} \mathrm{~N}$ enrichment of the residual N (Farrell et al. 1996; Garten and van Miegroet 1994). Plants in lower-lying portions of the landscape typically have higher $\delta^{15} \mathrm{~N}$ values than those in upland areas. In our study areas, high floral $\delta^{15} \mathrm{~N}$ values were identified in lowlying areas that were marshy or saline, as well as pastures located in the vicinity of towns.

The diversity of carbon isotopic variation visible in meadow steppes likely reflects localized differences in topography that impact water availability. In the grassland environments of the Great Plains and Inner Mongolia, regions characterized by undulating topographic relief, floral growth in wetter areas such as depressions exhibits low $\delta^{13} \mathrm{C}$ values relative to those in upland areas (Tieszen and Bingyu 1990; Tieszen 1994). Localized soil salinity may also contribute to the wide range of $\delta^{13} \mathrm{C}$ variation in steppe meadows and in some cases may induce water stress in floral growth, even for plants growing water depressions that would otherwise support ${ }^{13} \mathrm{C}$ depleted floral growth. In the case of Bestamak, low $\delta^{15} \mathrm{~N}$ values were located in upland meadow steppe areas with low soil salinity.

Comparatively, in open steppe areas, the 4.9 to $7.1 \%$ enrichment of plants from Lisakovsk to those at Bestamak likely reflects a higher stocking rate at the former study site. The Lisakovsk study area is located in the vicinity of a large town, and local populations use the steppe landscapes for intensive grazing of livestock year-round. Together, these factors contribute to ${ }^{15} \mathrm{~N}$ enriched plants at Lisakovsk via the continuous amendment of soils with exogenous nitrogen in the form of manure (Bol et al. 2005). Animal-derived nitrogen may be delivered to plants through purposeful application of manures or increased grazing intensity (Li et al. 2010; Xu et al. 2010).
Fig. 4 Ancient livestock bone collagen $\delta^{13} \mathrm{C}$ and $\delta^{15} \mathrm{~N}$ values from the sites of Kamennyi Ambar (MBA),

Bolshekaragansky (MBA), Bestamak (MBA), and Lisakovsk (LBA)

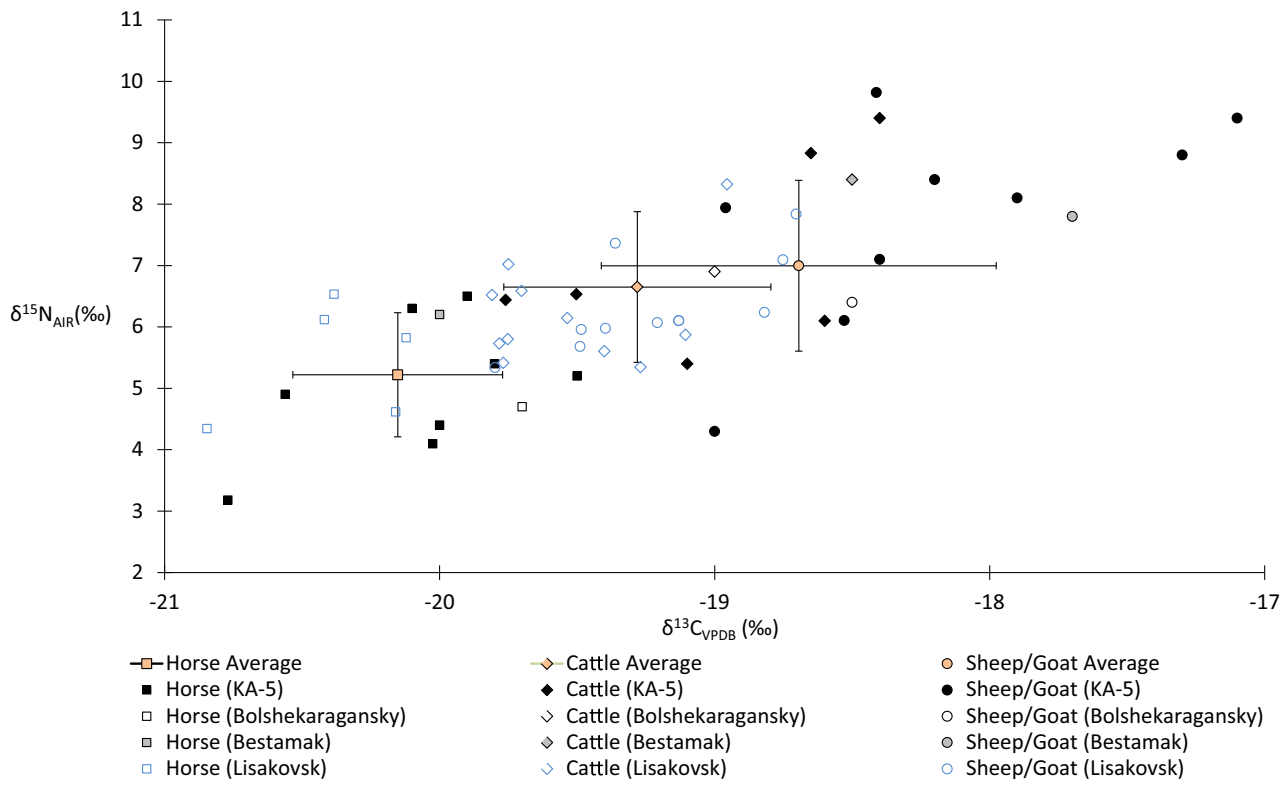


Table 5 Carbon and nitrogen values for ancient livestock by site

\begin{tabular}{|c|c|c|c|c|c|c|c|c|}
\hline \multirow[b]{2}{*}{ Bronze Age livestock } & \multicolumn{4}{|c|}{$\delta^{13} \mathrm{C}(\% \circ)$} & \multicolumn{4}{|c|}{$\delta^{15} \mathrm{~N}(\% o)$} \\
\hline & Min & Max & Mean & $1 \sigma$ & Min & $\operatorname{Max}$ & Mean & $1 \sigma$ \\
\hline Kamennyi Ambar 5 (MBA) & -20.8 & -17.1 & -19.1 & 1.0 & 3.2 & 9.8 & 6.6 & 1.9 \\
\hline Horse $(n=8)$ & -20.8 & -19.5 & -20.1 & 0.4 & 3.2 & 6.5 & 5.0 & 1.1 \\
\hline Cattle $(n=6)$ & -19.8 & -18.4 & -19.0 & 0.5 & 5.4 & 9.4 & 7.1 & 1.6 \\
\hline Sheep/goat $(n=9)$ & -19.0 & -17.1 & -18.2 & 0.7 & 4.3 & 9.8 & 7.8 & 1.7 \\
\hline Bolshekaragansky (MBA) & -19.7 & -18.5 & -19.1 & 0.6 & 4.7 & 6.9 & 6.0 & 1.2 \\
\hline Horse $(n=1)$ & -19.7 & -19.7 & -19.7 & - & 4.7 & 4.7 & 4.7 & - \\
\hline Cattle $(n=1)$ & -19.0 & -19.0 & -19.0 & - & 6.9 & 6.9 & 6.9 & - \\
\hline Sheep/goat $(n=1)$ & -18.5 & -18.5 & -18.5 & - & 6.4 & 6.4 & 6.4 & - \\
\hline Bestamak (MBA) & -20.0 & -17.7 & -18.7 & 1.2 & 6.2 & 8.4 & 7.5 & 1.1 \\
\hline Horse $(n=1)$ & -20.0 & -20.0 & -20.0 & - & 6.2 & 6.2 & 6.2 & - \\
\hline Cattle $(n=1)$ & -18.5 & -18.5 & -18.5 & - & 8.4 & 8.4 & 8.4 & - \\
\hline Sheep/goat $(n=1)$ & -17.7 & -17.7 & -17.7 & - & 7.8 & 7.8 & 7.8 & - \\
\hline Lisakovsk (LBA) & -20.8 & -18.7 & -19.6 & 0.5 & 4.3 & 8.3 & 6.1 & 0.9 \\
\hline Horse $(n=5)$ & -20.8 & -20.1 & -20.4 & 0.3 & 4.3 & 6.5 & 5.5 & 1.0 \\
\hline Cattle $(n=11)$ & -19.8 & -19.0 & -19.5 & 0.3 & 5.3 & 8.3 & 6.2 & 0.9 \\
\hline Sheep/goat $(n=11)$ & -19.8 & -18.7 & -19.2 & 0.3 & 5.3 & 7.8 & 6.3 & 0.8 \\
\hline
\end{tabular}

The absence of a relationship between stocking rate and the $\delta^{15} \mathrm{~N}$ of soil, vegetation, and livestock, previously observed for sheep grazing in a semi-arid grassland steppe (Wittmer et al. 2011; Auserwald et al., 2012), is likely due to a combination of a relatively low stocking rate $(0.375-2.25$ sheep $\mathrm{ha}^{-1} \mathrm{a}^{-1}$ ) and low soil nitrogen retention. The investigation of single season grazing on summer pastures, and the exclusion of winter pastures that tend to be grazed for longer periods of time and at greater intensity, may have led to low variation in the $\delta^{15} \mathrm{~N}$ of livestock tissues.

\section{$\delta^{13} \mathrm{C}$ and $\delta^{15} \mathrm{~N}$ values in livestock record pasture use}

The pattern of bone collagen $\delta^{13} \mathrm{C}$ values of domestic animals, ranging from -20.8 to $-18.5 \%$ o, strongly suggests that ancient livestock lived in an open environment dominated mainly by $\mathrm{C}_{3}$ plants. A wide range of variation in $\delta^{13} \mathrm{C}$ and $\delta^{15} \mathrm{~N}$ values for ruminants at the site of Kamennyi Ambar (MBA) compared to the site of Lisakovsk (LBA) was evident, with $\delta^{13} \mathrm{C}$ values of 2.7 and $1.1 \%$ respectively, and with $\delta^{15} \mathrm{~N}$ of 2.8 and $2.0 \%$, respectively. Wider variation evident among ruminants indicates that animal management strategies at the site of Kamennyi Ambar involved placing animals on pastures with high plant diversity or that livestock were led to pastures over a broader region.

Foregut ruminants, such as cattle and caprines, have different physiologies than horses which are foregut fermenters (Menard et al. 2002), yet when fed identical diets, they have similar isotopic signatures (Sponheimer et al. 2003a, 2003b). Horses and cattle have high niche overlap, grazing on the same resources (Menard et al. 2002), with selection of oldfield grasslands in all seasons. However, when presented with the opportunity, horses will feed in wet and moderately wet grasslands (Menard et al. 2002), which were likely exploited by herders in the Bronze Age. Our isotopic data suggests horses were grazed extensively across the steppe, while ruminants were grazed intensively in pastures with more isotopically variable plant communities, often located in close proximity to settlements.

At Bestamak, the combination of low $\delta^{13} \mathrm{C}$ and $\delta^{15} \mathrm{~N}$ values visible in horses suggests that they grazed on elevated open steppe zones supporting pastures characterized by low carbon and nitrogen plant values as visible in the modeled isoscapes. In addition, horses may have grazed on ${ }^{13} \mathrm{C}$-depleted forage in well-watered meadow steppe pastures that had moderate $\delta^{15} \mathrm{~N}$ values $\left(3.3 \%\right.$ ) . The pattern of ${ }^{13} \mathrm{C}$ enrichment in cattle and caprines at Bestamak suggests that these animals grazed more often in saline and brackish marshes, or drier steppe meadows, comparable to those located near the center, southern, and eastern portions of the study area. Taken together, our results suggest that horses were grazed extensively over broader areas, while ruminants were grazed extensively in areas adjacent to settlements. As the contemporary Bestamak study area supports low human population and herd density, it may be that in prehistory greater anthropogenic effects alongside those from intensive grazing significantly altered the nitrogen isotopic composition of plants. The addition of animal manure increases plant $\delta^{15} \mathrm{~N}$ values depending on the type, amount, and duration of application (Bogaard et al. 2007; Fraser et al. 2011; Szpak et al. 2012; Makarewicz 2014). 
Fig. 5 Modern plants (adjusted by $+1.5 \%$ o to correct for the Seuss effect) alongside ancient livestock from Lisakovsk

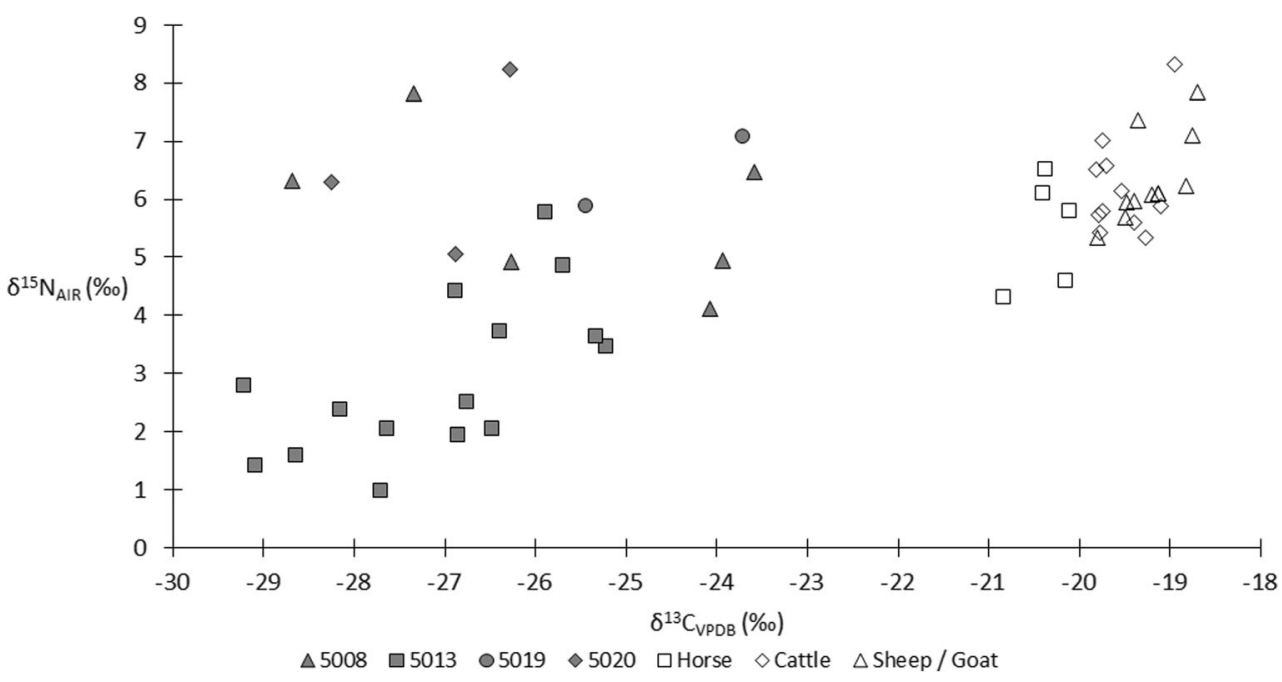

Isoscapes from the Lisakovsk study area are relatively homogeneous, with ${ }^{13} \mathrm{C}$-depleted and ${ }^{15} \mathrm{~N}$-enriched vegetation compared to Bestamak. Within this zone, there is variation, such as plants with low $\delta^{13} \mathrm{C}$ and $\delta^{15} \mathrm{~N}$ values in the vicinity of the freshwater lake (unit 5013) in the northern portion of the study area, or in small vegetation communities to the south or east encompass well-watered meadow steppes (Fig. 5). Ancient horses were depleted in ${ }^{13} \mathrm{C}$ and ${ }^{15} \mathrm{~N}$ relative to other livestock and grazed on plants with lower isotopic compositions, such as those found at the edges of freshwater lakes. Alternatively, horses could have accessed pastures that were less intensively grazed that fall outside of the study area in vegetation communities similar to those at Bestamak. The nitrogen isotopic composition of pastures located in close proximity to the ancient settlement may have been higher than those further away due to intensive landscape use. High nitrogen values across the modern landscape are likely due to intensive grazing or anthropogenic effects, which would likely have been less drastic in prehistory due to smaller population and herd sizes. The pattern of ${ }^{13} \mathrm{C}$ and ${ }^{15} \mathrm{~N}$ enrichment in ancient cattle and caprines at Lisakovsk compared to horses suggests ruminants grazed on pasturage located in saline or brackish marshes, and sedge marshes located near waterways, such as the Tobol River which cross-cuts the study area from west to east. A wide range of isotopic variation among cattle and caprines may indicate that were separated into multiple small herds that grazed on distinct pastures (Fig. 6).

\section{Conclusion}

A major shift in patterns of settlement occurred at the Middle to Late Bronze Age transition, from large semi-sedentary populations in enclosed settlements to smaller populations in open settlements dispersed across the landscape. Scholars have suggested that animal management strategies also changed at this time from semi-sedentary pastoralism to more mobile forms of pastoral nomadism. However, our findings suggest that livestock management practices did not shift in concert with social landscapes, demonstrating consistency in pastoral adaptations through time in the region. Similar isotopic patterning between livestock during the MBA and LBA across several sites in the CES indicates that there were no changes across time in pasture usage patterns. Among ancient livestock, differences in $\delta^{13} \mathrm{C}$ and $\delta^{15} \mathrm{~N}$ values between horses and ruminants (cattle, sheep, goat) strongly suggest that livestock were grazed pastures either extensively or intensively, respectively. Horses grazed in open steppe areas or intermittently in areas with well-watered soils that lacked salinity, likely staying well outside of settlements. In contrast, cattle and sheep/goat grazed in pastures across multiple zones, both near the settlement and in non-local pastures that were grazed intensively. A wider range of $\delta^{13} \mathrm{C}$ and $\delta^{15} \mathrm{~N}$ values among ruminants at Kamennyi Ambar (MBA) suggests that aggregated human populations may have had larger herds, some of which accessed non-local pastures outside of the easily accessible territories surrounding enclosed sites. Continued

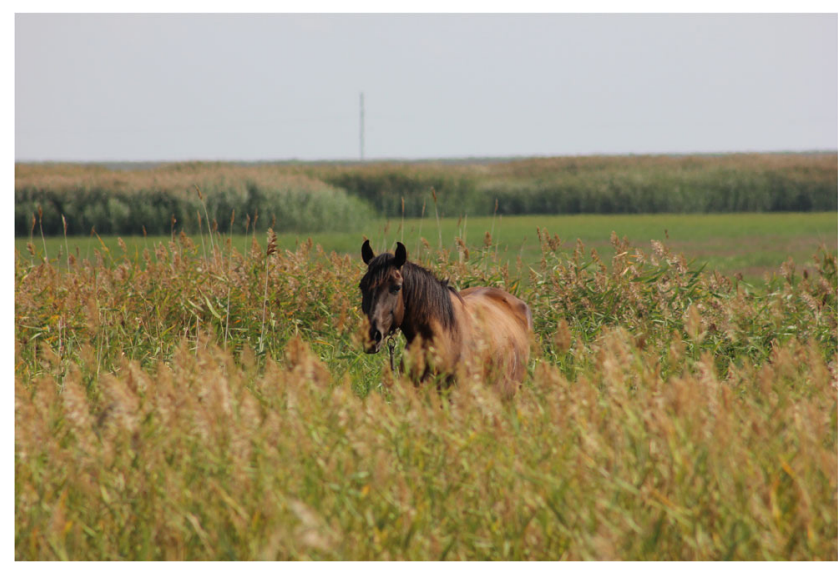

Fig. 6 A horse grazing in a marsh area in the Lisakovsk study area 
research on the isotopic composition of vegetation surrounding Bronze Age sites should clarify patterns of landscape use between MBA sites.

Acknowledgements Stable isotopic research and data analysis for this manuscript were undertaken at the Archaeological Stable Isotope Laboratory (ASIL) at the University of Kiel. The authors are indebted to colleagues who assisted with the collection of samples in the field, especially Bryan Miller and Asa Cameron. Isoscapes were reconfigured with the help of Nils Vanwezer from the Max Planck Institute for the Science of Human History.

Funding information Open access funding provided by Max Planck Society. AVM received support from the Gerda Henkel Foundation (Grant No. AZ 25/V/14) to undertake environmental sampling for this project. Support for isotopic analyses was funded by the Graduate School Human Development in Landscapes (GSHDL) and the Archeological Stable Isotope Laboratory (ASIL) at the University of Kiel.

Open Access This article is distributed under the terms of the Creative Commons Attribution 4.0 International License (http:// creativecommons.org/licenses/by/4.0/), which permits unrestricted use, distribution, and reproduction in any medium, provided you give appropriate credit to the original author(s) and the source, provide a link to the Creative Commons license, and indicate if changes were made.

\section{References}

Amundson R, Austin AT, Schuur EA, Yoo K, Matzek V, Kendall C, Uebersax A, Brenner D, Baisden WT (2003) Global patterns of the isotopic composition of soil and plant nitrogen. Glob Biogeochem Cycles 17(1)

Anthony David, W. 2007. The horse, the wheel and language. How bronze-age riders from the steppes shaped the modern world. Princeton University Press

Auerswald K, Wittmer M, Männel T, Bai Y, Schäufele R, Schnyder H (2009) Large regional-scale variation in C3/C4 distribution pattern of Inner Mongolia steppe is revealed by grazer wool carbon isotope composition. Biogeosciences 6(5):795-805

Auerswald K, Wittmer MH, Bai Y, Yang H, Taube F, Susenbeth A, Schnyder H (2012) C4 abundance in an Inner Mongolia grassland system is driven by temperature-moisture interaction, not grazing pressure. Basic Appl Ecology 13(1):67-75

Batanina, N. S., \& Hanks, B. K. 2013. Soviet period air photography and archaeology of the bronze age in the southern Urals of Russia. In: W. S. Hanson and I. A. Oltean, eds. Archaeology from Historical Aerial and Satellite Archives. Springer, pp. 199-219

Bogaard A, Heaton TH, Poulton P, Merbach I (2007) The impact of manuring on nitrogen isotope ratios in cereals: archaeological implications for reconstruction of diet and crop management practices. $\mathrm{J}$ Archaeol Sci 34(3):335-343

Bol R, Eriksen J, Smith P, Garnett MH, Coleman K, Christensen BT (2005) The natural abundance of ${ }^{13} \mathrm{C},{ }^{15} \mathrm{~N},{ }^{34} \mathrm{~S}$ and ${ }^{14} \mathrm{C}$ in archived (1923-2000) plant and soil samples from the Askov long-term experiments on animal manure and mineral fertilizer. Rapid Commun Mass Spectrom 19:3216-3226

Bowen GJ (2010) Isoscapes: spatial pattern in isotopic biogeochemistry. Annu Rev Earth Planet Sci 38:161-187

Bowman WD, Hubick KT, von Caemmerer S, Farquhar GD (1989) Short-term changes in leaf carbon isotope discrimination in saltand water-stressed C4 grasses. Plant Physiol 90(1):162-166

Bragina TM (2016) Soil macrofauna (invertebrates) of Kazakhstanian Stipa lessingiana dry steppe. Hacquetia 15:105-112
Cloern JE, Canuel EA, Harris D (2002) Stable carbon and nitrogen isotope composition of aquatic and terrestrial plants of the San Francisco Bay estuarine system. Limnol Oceanogr 47:713-729

De Pauw, E. 2007. Principal biomes of Central Asia. Climate Change and Terrestrial Carbon Sequestration in Central Asia, 3-24

Deák B, Tóthmérész B, Valkó O, Sudnik-Wójcikowska B, Moysiyenko II, Bragina TM, Apostolova I, Dembicz I, Bykov NI, Török P (2016) Cultural monuments and nature conservation: a review of the role of kurgans in the conservation and restoration of steppe vegetation. Biodivers Conserv 25:2473-2490

DeNiro MJ, Epstein S (1978) Influence of diet on the distribution of carbon isotopes in animals. Geochim Cosmochim Acta 42(5):495506

Ehleringer J, Field C, Lin Z, Kuo C (1986) Leaf carbon isotope and mineral composition in subtropical plants along an irradiance cline. Oecologia 70:520-526

Epimakhov, A. V. 2002. Complex societies and the possibilities to diagnose them on the basis of archaeological data: Sintashta type sites of the middle bronze age of the trans-Urals. In: K. Jones-Bley and D.G. Zdanovich, eds. Complex societies of central Eurasia from the $3^{\text {rd }}$ to 1st millennium BC, Vol II. Institute for the Study of man: Washington, DC, pp. 139-47

Epimakhov, A.V. 2009. Settlements and cemeteries of the Bronze Age of the Urals: the potential for reconstructing early social dynamics. In B. K. Hanks \& K. M. Linduff (Eds.), Social complexity in prehistoric Eurasia: Monuments, Metals and Mobility. Cambridge: Cambridge University, pp. 74-90

Evans, R. D. 2007. Soil nitrogen isotope composition. Stable isotopes in ecology and environmental science, 2, 83-98

Farquhar G (1991) Use of stable isotopes in evaluating plant water use efficiency. Stable Isotopes in Plant Nutrition, Soil Fertility and Environ Studies, $475-488$

Farquhar GD, O'Leary MH, Berry JA (1982a) On the relationship between carbon isotope discrimination and the intercellular carbon dioxide concentration in leaves. Funct Plant Biol 9(2):121-137

Farquhar G, Ball M, Von Caemmerer S, Roksandic Z (1982b) Effect of salinity and humidity on $\delta^{13} \mathrm{C}$ value of halophytes - evidence for diffusional isotope fractionation determined by the ratio of intercellular/atmospheric partial pressure of $\mathrm{CO} 2$ under different environmental conditions. Oecologia 52(1):121-124

Farquhar GD, Ehleringer JR, Hubick KT (1989) Carbon isotope discrimination and photosynthesis. Annu Rev Plant Biol 40(1):503-537

Farrell RE, Sandercock PJ, Pennock DJ, Van Kessel C (1996) Landscapescale variations in leached nitrate: relationship to denitrification and natural nitrogen-15 abundance. Soil Sci Soc Am J 60:1410-1415

Fernandez-Gimenez ME (2000) The role of Mongolian nomadic pastoralists' ecological knowledge in rangeland management. Ecol Appl 10:1318-1326

Fernandez-Gimenez ME (2002) Spatial and social boundaries and the paradox of pastoral land tenure: a case study from postsocialist Mongolia. Hum Ecol 30:49-78

Frachetti, M.D., 2009. Differentiated landscapes and non-uniform complexity among Bronze Age societies of the Eurasian steppe. In B. K. Hanks \& K. M. Linduff, eds. Social complexity in prehistoric Eurasia: Monuments, Metals and Mobility. Cambridge: Cambridge University Press, pp. 19-46

Fraser RA, Bogaard A, Heaton T, Charles M, Jones G, Christensen BT, Halstead P, Merback I, Poulton PR, Sparkes D, Styring AK (2011) Manuring and stable nitrogen isotope ratios in cereals and pulses: towards a new archaeobotanical approach to the inference of land use and dietary practices. J Archaeol Sci 38(10):2790-2804

Garten Jr CT, Miegroet HV (1994) Relationships between soil nitrogen dynamics and natural ${ }^{15} \mathrm{~N}$ abundance in plant foliage from great Smoky Mountains National Park. Can J For Res 24:1636-1645 
Gening, V., Zdanovich, G., \& Gening, V. 1992. Sintashta: archeological sites of Aryan Tribes of the Ural-Kazakh steppes. Russian Academy of Sciences: Chelyabinsk. (In Russian)

Grigor'yev, S. A. 2002. Ancient Indo-Europeans. Rifei Chelyabinsk. (In Russian)

van Groenigen J-W, van Kessel C (2002) Salinity-induced patterns of natural abundance carbon-13 and nitrogen-15 in plant and soil. Soil Sci Soc Am J 66(2):489-498

Handley L, Austin A, Stewart G, Robinson D, Scrimgeour C, Raven J, Schmidt S (1999) The ${ }^{15} \mathrm{~N}$ natural abundance $\left(\delta^{15} \mathrm{~N}\right)$ of ecosystem samples reflects measures of water availability. Funct Plant Biol 26(2):185-199

Hanks BK (2009) Late prehistoric mining, metallurgy, and social Organization in North Central Eurasia. In B. K. Hanks \& K. M. Linduff (Eds.), Social complexity in prehistoric Eurasia: Monuments, Metals and Mobility. Cambridge: Cambridge University Press, pp. 146-167

Hanks BK, Ventresca Miller A, Epimakhov A, Judd M, Rajev D, Privat K, Rosenmeier M (2018) Examination of multi-resource pastoralism and dietary trends in Bronze Age north central Eurasia. Journal of Archaeological Science (forthcoming)

Heaton TH (1987) The ${ }^{15} \mathrm{~N} /{ }^{14} \mathrm{~N}$ ratios of plants in South Africa and Namibia: relationship to climate and coastal/saline environments. Oecologia 74:236-246

Hedges RE, Clement JG, Thomas CDL, O'Connell TC (2007) Collagen turnover in the adult femoral mid-shaft: modeled from anthropogenic radiocarbon tracer measurements. Am J Phys Anthropol 133:808816

Hokmabadi H, Arzani K, Grierson P (2005) Growth, chemical composition, and carbon isotope discrimination of pistachio (Pistacia vera L.) rootstock seedlings in response to salinity. Crop Pasture Sci 56(2):135-144

Honeychurch W, Makarewicz CA (2016) The archaeology of pastoral nomadism. Annu Rev Anthropol 45:341-359

Ilyakova R, Monkaeva G, Dolgikh S, Smirnova E (2015) Annual bulletin of climate change monitoring in Kazakhstan: 2014. Ministry of Energy of the Republic of Kazakhstan, Astana

Keeling CD (1979) The Suess effect: ${ }^{13}$ Carbon $-{ }^{14}$ Carbon interrelations. Environ Int 2:229-300

Kerven C, Alimaev II, Behnke R, Davidson G, Malmakov N, Smailov A, Wright I (2006) Fragmenting pastoral mobility: changing grazing patterns in post-Soviet Kazakhstan. USDA Forest Service Proceedings RMRS-P-39, 99-110

Kerven C, Robinson S, Behnke R, Kushenov K, Milner-Gulland E (2016) Horseflies, wolves and wells: biophysical and socioeconomic factors influencing livestock distribution in Kazakhstan's rangelands. Land Use Policy 52:392-409

Kohl, P. L. 2007. The making of Bronze Age Eurasia. Cambridge University Press

Koryakova L, Epimakhov AV (2007) The Urals and western Siberia in the Bronze and Iron ages. Cambridge University Press

Krause, R., \& Koryakova, L. N., eds.. 2013. Multidisciplinary investigations of the Bronze Age settlements in the Southern Trans-Urals (Russia). Habelt Bonn

Kremenetski C, Tarasov P, Cherkinsky A (1997a) Postglacial development of Kazakhstan pine forests. Geographie Physique et Quaternaire 51(3):391-404

Kremenetski C, Tarasov P, Cherkinsky A (1997b) The latest pleistocene in southwestern Siberia and Kazakhstan. Quat Int 41:125-134

Kremenetski C V (1997) The Late Holocene environmental and climate shift in Russia and surrounding lands. In Third millennium BC climate change and old world collapse (pp. 351-370). Springer

Kuz'mina, E. 2007. The origin of the Indo-Iranians/Transl. by S. Pitina and P. Prudovsky. Ed. by JP Mallory. Leiden Indo-European Etymological Dictionary Series._-Leiden: Brill
Lajtha K, Getz J (1993) Photosynthesis and water-use efficiency in pinyon-juniper communities along an elevation gradient in northern New Mexico. Oecologia 94(1):95-101

Li C, Hao X, Willms WD, Zhao M, Han G (2010) Effect of long-term cattle grazing on seasonal nitrogen and phosphorus concentrations in range forage species in the fescue grassland of southwestern Alberta. J Plant Nutr Soil Sci 173:946-951

Liu X, Wang R, Li Y (2004) Photosynthetic pathway types in rangeland plant species from Inner Mongolia, North China. Photosynthetica 42(3):339-344

Makarewicz CA (2014) Winter pasturing practices and variable fodder provisioning detected in nitrogen $\left(\delta^{15} \mathrm{~N}\right)$ and carbon $\left(\delta^{13} \mathrm{C}\right)$ isotopes in sheep dentinal collagen. J Archaeol Sci 41:502-510

Makarewicz CA (2017) Sequential $\delta^{13} \mathrm{C}$ and $\delta^{18} \mathrm{O}$ analyses of early Holocene bovid tooth enamel: resolving vertical transhumance in Neolithic domesticated sheep and goats. Palaeogeogr Palaeoclimatol Palaeoecol 485:16-29

Makarewicz C, Tuross N (2006) Foddering by Mongolian pastoralists is recorded in the stable carbon $\left(\delta^{13} \mathrm{C}\right)$ and nitrogen $\left(\delta^{15} \mathrm{~N}\right)$ isotopes of caprine dentinal collagen. J Archaeol Sci 33(6):862-870

Menard C, Duncan P, Fleurance G, Georges JY, Lila M (2002) Comparative foraging and nutrition of horses and cattle in European wetlands. J Appl Ecol 39(1):120-133

Merrony, C., Hanks, B., \& Doonan, R. 2009. Seeking the process: the application of geophysical survey on some early mining and metalworking sites. Metals and Societies. Studies in Honour of Barbara S. Ottaway. Universitätsforschungen Zur Prähistorischen Archäologie. Bonn: Habelt, pp. 421-429

Milner-Gulland E, Kerven C, Behnke R, Wright I, Smailov A (2006) A multi-agent system model of pastoralist behaviour in Kazakhstan. Ecol Complex 3(1):23-36

Motuzaite Matuzeviciute G, Lightfoot E, O’Connell TC, Voyakin D, Liu X, Loman V, Svyatko S, Usmanova E, Jones MK (2015) The extent of cereal cultivation among the Bronze Age to Turkic period societies of Kazakhstan determined using stable isotope analysis of bone collagen. J Archaeol Sci 59:23-34. https://doi.org/10.1016/j.jas. 2015.03.029

Murphy BP, Bowman DM (2009) The carbon and nitrogen isotope composition of Australian grasses in relation to climate. Funct Ecol 23(6): 1040-1049

Ng, C. Y. 2013. Archaeobotanical evidence for Bronze Age subsistence economy and social complexity (2100-1750 BCE) at the Stepnoye settlement, Russia. 4-8 September. Pilsen: The 19th annual meeting of the European Association of Archaeologists

O'Leary MH (1981) Carbon isotope fractionation in plants. Phytochemistry 20(4):553-567

O'Leary MH (1988) Carbon isotopes in photosynthesis. Bioscience 38(5):328-336

Outram, A. 2015. Pastoralism. In: G. Barker and C. Goucher, eds. The Cambridge World History: Volume 2, A World with Agriculture, 12, 000 BCE-500 CE. Cambridge University press, pp. 161-185

Privat, K. 2004. Palaeoeconomy of the Eurasian steppe: biomolecular studies. $\mathrm{PhD}$ thesis, University of Cambridge

R Development Core Team. R: A language and environment for statistical computing. R Foundation for Statistical Computing (Vienna, 2016). URL http://www.R-project.org/

Rachkovskaya, E., \& Bragina, T. 2012. Steppes of Kazakhstan: diversity and present state. In Eurasian Steppes. Ecological Problems and Livelihoods in a Changing World. Springer, pp. 103-148

Robinson S, Milner-Gulland E, Alimaev I (2003) Rangeland degradation in Kazakhstan during the soviet era: re-examining the evidence. J Arid Environ 53:419-439

Schillhorn van Veen, T.W., Alimaev, I. and B. Utkelov. 2003. Kazakhstan: Rangelands in Transition: the Resource, the Users and Sustainable Use. Astana: World Bank 
Shishlina N, Zazovskaya E, van der Plicht J, Sevastyanov V (2012) Isotopes, plants, and reservoir effects: case study from the Caspian Steppe Bronze Age. Radiocarbon 54:749-760

Sponheimer M, Robinson T, Ayliffe L, Roeder B, Hammer J, Passey B, West A, Cerling T, Dearing D, Ehleringer J (2003a) Nitrogen isotopes in mammalian herbivores: hair $\delta 15 \mathrm{~N}$ values from a controlled feeding study. Int J Osteoarchaeol 13(1-2):80-87

Sponheimer M, Robinson T, Ayliffe L, Passey B, Roeder B, Shipley L, Lopez E, Cerling T, Dearing D, Ehleringer J (2003b) An experimental study of carbon-isotope fractionation between diet, hair, and feces of mammalian herbivores. Can J Zool 81(5):871-876

Stewart GR, Turnbull MH, Schmidt S, Erskine PD (1995) ${ }^{13} \mathrm{C}$ natural abundance in plant communities along a rainfall gradient: a biological integrator of water availability. Funct Plant Biol 22(1):51-55

Stobbe A, Gumnior M, Röpke A, Schneider H (2015) Palynological and sedimentological evidence from the trans-ural steppe (Russia) and its palaeoecological implications for the sudden emergence of Bronze Age sedentarism. Veg Hist Archaeobotany 24(3):393-412

Stobbe A, Gumnior M, Rühl L, Schneider H (2016) Bronze aAge human-landscape interactions in the southern Transural steppe, Russia-evidence from high-resolution palaeobotanical studies. The Holocene 26(10):1692-1710

Swap R, Aranibar J, Dowty P, Gilhooly W, Macko SA (2004) Natural abundance of ${ }^{13} \mathrm{C}$ and ${ }^{15} \mathrm{~N}$ in $\mathrm{C}_{3}$ and $\mathrm{C}_{4}$ vegetation of southern Africa: patterns and implications. Glob Chang Biol 10(3):350-358

Szpak P (2014) Complexities of nitrogen isotope biogeochemistry in plant-soil systems: implications for the study of ancient agricultural and animal management practices. Front Plant Sci 5:288

Szpak P, Millaire J-F, White CD, Longstaffe FJ (2012) Influence of seabird guano and camelid dung fertilization on the nitrogen isotopic composition of field-grown maize (Zea mays). J Archaeol Sci 39(12):3721-3740

Szpak P, White CD, Longstaffe FJ, Millaire J-F, Sánchez VFV (2013) Carbon and nitrogen isotopic survey of northern Peruvian plants: baselines for paleodietary and paleoecological studies. PLoS One $8(1): \mathrm{e} 53763$

Terzopoulos D (1988) The computation of visible-surface representations. IEEE Trans Pattern Anal Mach Intell 10:417-438

Tieszen LL (1994) Stable isotopes on the plains: vegetation analyses and diet determinations. In: Skeletal Biology in the Great Plains. pp 261-82

Tieszen L, Bingyu S (1990) Stable carbon isotopic variation among plants of the Inner Mongolian grasslands. Reports from the Inner Mongolia grassland ecosystem research station of Academia Sinica (19791988)

Tieszen LL, Boutton TW, Tesdahl KG, Slade NA (1983) Fractionation and turnover of stable carbon isotopes in animal tissues: implications for $\delta^{13} \mathrm{C}$ analysis of diet. Oecologia 57:32-37

Tkacheva, N. A. 1999. Dynamics and character in the development of Bronze Age settlement complexes in the upper Irtish. J Archaeology, Anthropology Ethnography 2. (In Russian)

Tkacheva N, Tkachev A (2008) The role of migration in the evolution of the Andronov community. Archaeol Ethnol Anthropol Eurasia 35(3):88-96

Toderich, K., Black, C. C., Juylova, E., Kozan, O., Mukimov, T., \& Matsuo, N. 2007. C3/C4 plants in the vegetation of Central Asia, geographical distribution and environmental adaptation in relation to climate. Carbon Management and Sequestration in Drylands of Central Asia. Balkema Publishers, Netherlands, 33-63

Ventresca Miller AR, Usmanova E, Logvin V, Kalieva S, Shevnina I, Logvin A, Kolbina A, Suslov A, Privat K, Haas K (2014a) Subsistence and social change in central Eurasia: stable isotope analysis of populations spanning the Bronze Age transition. J Archaeol Sci 42:525-538

Ventresca Miller A, Usmanova ER, Logvin VN, Kalieva S, Shevnina I, Logvin A, Kolbina A, Suslov A (2014b) Dental health, diet, and social transformations in the Bronze Age: comparative analysis of pastoral populations in northern Kazakhstan. Quat Int 348:130-146

Virginia RA, Delwiche CC (1982) Natural $15 \mathrm{~N}$ abundance of presumed $\mathrm{N} 2$-fixing and non-N 2-fixing plants from selected ecosystems. Oecologia 54(3):317-325

Wang G, Li J, Liu X, Li X (2013) Variations in carbon isotope ratios of plants across a temperature gradient along the $400 \mathrm{~mm}$ isoline of mean annual precipitation in north China and their relevance to paleovegetation reconstruction. Quat Sci Rev 63:83-90

Wei L, Yan C, Ye B, Guo X (2008) Effects of salinity on leaf $\delta^{13}$ C in three dominant mangrove species along salinity gradients in an estuarine wetland, Southeast China. J Coast Res 241:267-272

West, J.B., Bowen, G.J., Dawson, T.E., \& Tu, K.P. 2010. Isoscapes. Springer

Wittmer MH, Auerswald K, Bai Y, Schaeufele R, Schnyder H (2010) Changes in the abundance of $\mathrm{C} 3 / \mathrm{C} 4$ species of Inner Mongolia grassland: evidence from isotopic composition of soil and vegetation. Glob Chang Biol 16(2):605-616

Wittmer MH, Auerswald K, Schönbach P, et al (2011) N fractionation between vegetation, soil, faeces and wool is not influenced by stocking rate. Plant Soil 340:25-33

Wright J, Makarewicz C (2015) Perceptions of pasture: the role of skill and networks in maintaining stable pastoral nomadic systems in Inner Asia. Ancient Soc Climate:267-288

Wunder, M. B. 2010. Using isoscapes to model probability surfaces for determining geographic origins. In: J. B. West, G. J. Bowen, T. E. Dawson, \& K. P. Tu, eds. Isoscapes. Springer, pp. 251-270

Xu Y, He J, Cheng W, Xing X, Li L (2010) Natural ${ }^{15} \mathrm{~N}$ abundance in soils and plants in relation to $\mathrm{N}$ cycling in a rangeland in Inner Mongolia. J Plant Ecol 3:201-207

Yakir D (2011) The paper trail of the ${ }^{13} \mathrm{C}$ of atmospheric CO2 since the industrial revolution period. Environ Res Letters 6:034007

Zakh VA, Ilyushina VV (2010) Ware of the Fedorovo Culture in the Lower Tobol: based on material from the settlement Cheremukhovyi Kust. J Archaeology, Anthropology Ethnography 2(13):42-50 (In Russian)

Zdanovich, G. B., \& Batanina, I. M. 2002. Planography of the fortified centers of the middle Bronze Age in the Southern Trans-Urals according to aerial photography data. In: K. Jones-Bley and D.G. Zdanovich, eds. Complex Societies of Central Eurasia from the $3^{\text {rd }}$ to 1st Millennium BC, Vol II. Institute for the Study of Man: Washington, DC, pp. 121-147

Zhou J, Wu Y, Zhang J, Kang Q, Liu Z (2006) Carbon and nitrogen composition and stable isotope as potential indicators of source and fate of organic matter in the salt marsh of the Changjiang estuary, China. Chemosphere 65:310-317 